\title{
REGIME JURÍDICO DO PLÁGIO E SUA APLICABILIDADE NO CAMPO DE OBRA CIENTÍFICA (MONOGRAFIA JURÍDICA) - EXAME DE UM CASO CONCRETO
}

\author{
LEGAL DISCIPLINE OF PLAGIARISM AND ITS APPLICABILITY IN THE DOMAIN OF SCIENTIFIC \\ WORKS (LEGAL MONOGRAPHS) - CASE STUDY
}

José Carlos Costa Netto*

\begin{abstract}
Atendendo ao honroso convite do prestigioso Escritório Ribeiro \& Abrão Advogados, nas pessoas dos Drs. Renato Ribeiro e Jose Horácio Halfeld Rezende Ribeiro, em nome de seu constituinte, o jurista Professor Carlos Alberto Dabus Maluf, apresento a seguir meu
\end{abstract}

Parecer

sobre a matéria e questões específicas relacionadas a alegações de ocorrência de plágio, manifestadas em recurso à Reitoria da Universidade de São Paulo (USP), ilícito que supostamente teria sido praticado pelo jurista supra referido em sua tese que sagrouse vitoriosa no concurso público para o cargo de titularidade junto ao Departamento de Direito Civil da Faculdade de Direito de São Paulo intitulada "A Inexistência na Teoria das Nulidades", recurso este ora em curso no âmbito administrativo universitário.

1. Regime jurídico do plágio de obra intelectual

1.1. O princípio constitucional da liberdade de expressão da atividade intelectual e suas limitações legais

Como já tive a oportunidade de expressar em "Direito Autoral no Brasil", (2. edição, Editora FTD, São Paulo, 2008), ${ }^{1}$ a exemplo da emenda constitucional que se seguiu ao diploma de 1967, promulgada em 1969, a Constituição de 1988 reeditou, no Título "Dos Direitos e Garantias Fundamentais", Capítulo “Dos Direitos e Deveres

\footnotetext{
Advogado militante especializado em Direito Autoral, mestre e doutor em Direito Civil pela Faculdade de Direito da Universidade de São Paulo. Presidente da ABDA - Associação Brasileira de Direito Autoral e da BM\&A - Brasil, Música e Artes; membro do Comité International d'Honneur do MIDEM (Cannes, France), membro da Comissão de Propriedade Imaterial da OAB -Ordem dos Advogados do Brasil, Secção de São Paulo. E professor e coordenador do Curso de Direito de Entretenimento da ESA - Escola Superior de Advocacia (OAB/SP). O autor é convidado especial nesta matéria pelo Editor, desta Revista.

1 Obra citada, p. 172.
} 
Fundamentais", regra ampla de proteção autoral, ${ }^{2}$ da mesma forma que, em harmonia com a regra constitucional, a Lei Autoral de 1998 reeditou a regra da lei anterior. ${ }^{3}$

Assim, refiro-me, ainda ao fato de que - conjuntamente à proteção constitucional e infraconstitucional à proteção da criação intelectual com a concessão de "exclusivo" ao seu autor - convive, no mesmo patamar de "cláusulas pétreas" constitucionais (art. $5^{\circ}$ e seus incisos): "a liberdade de manifestação do pensamento e a liberdade de expressão da atividade intelectual, artística, científica e de comunicação, independentemente de censura ou licença". ${ }^{4}$

Acrescento, nesse ponto, que é natural que a hipótese de colidência desses princípios e direitos fundamentais em que o amplo espectro da incidência do direito exclusivo de utilização de obra intelectual pelo seu autor possa vir a ser conflitante com:

(a) a liberdade de manifestação do pensamento: quando, por exemplo, sem desrespeito aos direitos morais de autor, é publicado um posicionamento analítico e crítico sobre determinada obra intelectual protegida, com a reprodução elucidativa de trechos dessa obra;

(b) a liberdade de expressão da atividade intelectual, artística, científica e de comunicação: quando, por exemplo, sem violação dos direitos morais de autor, insira-se trechos de obra intelectual protegida ou em comentário a respeito desta, a título de informação, difundida por um veículo de comunicação (rádio, TV, internet etc.) ${ }^{5}$

Nesse caminho, concluo que

Assim, esses, entre outros inúmeros exemplos que poderão emergir dessa colidência de direitos fundamentais provocam a necessidade de que haja uma delimitação dessa região fronteiriça, mister que em sendo desenvolvido no âmbito das convenções internacionais e respectivas legislações internas - basicamente infraconstitucionais - dos países signatários que, conseqüentemente, endossam essas regras jurídicas no campo internacional, como ocorre, em relação ao direito positivo pátrio. ${ }^{6}$

E que

\footnotetext{
2 Inciso XXVII do artigo $5^{\circ}$ da Constituição Federal: “aos autores pertence o direito exclusivo de utilização, publicação ou reprodução de suas obras, transmissível aos herdeiros pelo tempo que a lei fixar".

3 Art. 29 da Lei n. 9.610/98 que consignou: "Cabe ao autor o direito exclusivo de utilizar, fruir e dispor da obra literária, artística ou científica".

4 Incisos IV e IX do art. $5^{\circ}$ da Constituição Federal. Obra citada, p. 172.

5 Obra citada, p. 174.

6 Obra citada, p. 174 e 175.
} 
o direito autoral, em decorrência de sua própria natureza, não conflita com a liberdade de manifestação de pensamento ou de expressão da atividade intelectual, artística, científica e de comunicação que utilizem idéias - contidas ou não em obras intelectuais protegidas - informações ou quaisquer outros elementos que não constituam em aproveitamento de obra intelectual alheia, considerada esta em seus aspectos originais de forma de expressão ${ }^{7}$

1.2. O direito de citação no contexto da garantia constitucional da liberdade de expressão da atividade intelectual científica

Seguindo, ainda, o exame que realizei em "Direito Autoral no Brasil" (2. Edição, 2008) reedito o meu entendimento de que a função social do direito de autor envolve o interesse público resultante da evidente relevância da democratização do acesso aos bens culturais. A região fronteiriça de delimitação do direito autoral se instala, portanto, de forma a atender determinadas demandas de fruição pública de obras intelectuais, bem como a interação entre os criadores intelectuais, necessárias ao desenvolvimento cultural da sociedade como um todo, na medida equilibrada que não venha a acarretar um esvaziamento "ou fragilização à proteção jurídica do direito autoral". ${ }^{8}$

Nesse contexto encontra-se incluído o denominado "direito de citação", que passamos a examinar, ainda na mesma forma que já o fizemos anteriormente. ${ }^{9}$

\subsubsection{Evolução legislativa}

Consoante já nos referimos, ${ }^{10}$ a primeira lei brasileira de direito de autor, de 1898, intitulada "Medeiros de Albuquerque", já se utilizava do recurso de elencar, a título exaustivo (não utilizando, portanto, a expressão "tais como” ou similar), as modalidades de utilização de obra intelectual que não seriam consideradas como ofensa aos direitos de autor. Da mesma forma, o nosso primeiro Código Civil, de 1916, adotou a mesma sistemática legal. ${ }^{11}$

\footnotetext{
Obra citada, p. 176.

8 Obra citada, p. 176 e 177. Complemento, na nota lateral n. 16, trazendo a lição de José de Oliveira Ascensão de que: "Os limites permitem conciliar o exclusivo atribuído ao autor com o interesse público e as posições de outros titulares. São fundamentais para a obtenção justa das finalidades do direito de autor". (Artigo "Direito de Autor e Desenvolvimento Tecnológico: Controvérsias e Estratégias", publicado na Revista de Direito Autoral n. 1, São Paulo, Edição ABDA/Lumen Juris, Agosto de 2004. p. 21).

9 "Direito Autoral no Brasil", ainda, p. 2. ed., 177-184.

10 Obra citada, p. 177.

11 Nos termos da nossa nota lateral n. 18 (obra citada, p. 177) o art. 666 do Código Civil de 1916, integrado por dez incisos, se limitou a introduzir alguns acréscimos e modificações ao elenco do art. 22 da Lei 496, de 1/8/1898, mantendo, portanto, a mesma orientação legal. Anota o jurista autor do Código Civil, CLÓVIS
} 
No âmbito dessas limitações, relevante à hipótese vertente a relativa à "reprodução de passagens ou trechos de obras já publicadas, e a inserção, ainda que integral, de pequenas composições alheias no corpo de obra maior, contanto que esta apresente caráter científico, ou seja compilação destinada a fim literário, didático ou religiosos, indicando-se, porém, a origem, de onde se tomaram os enxertos, bem como o nome do autor". ${ }^{12}$

Nesse passo, a lei regente para a matéria promulgada em 14.12.1973 ( $n$. 5.988), reeditou essa norma estabelecendo, em seu art. 49, inciso I, que "Não constitui ofensa aos direitos do autor: I - a reprodução: a) de trechos de obras já publicadas, ou ainda que integral, de pequenas composições alheias no contexto de obra maior, desde que esta apresente caráter científico, didático ou religioso, e haja a indicação da origem e do nome do autor;" e ainda, no inciso III do mesmo dispositivo legal:

a citação em livros, jornais e revistas, de passagens de qualquer obra, para fins de estudo, crítica ou polêmica.

\subsubsection{O regime legal vigente}

\subsubsection{A regra internacional}

Consoante expus na obra citada, ${ }^{1314}$ os dispositivos atualmente em vigor da Convenção de Berna relativa à proteção das obras literárias e artísticas relativa à proteção das obras literárias e artísticas, ${ }^{1415}$ em que é adotada a orientação de elencar as hipóteses de utilizações livres de obras intelectuais são os seus artigos "10" e "10bis", que estabelecem que:

(a) em relação ao direito de citação:

BEVILÁQUA, como fonte legislativa estrangeira, em relação a esse dispositivo, a lei alemã de 1901, artigos 19 a 24, a austríaca de 1895, artigos 25,26, 33 e 39, o Código Civil Mexicano de 1884, artigo 1.207, a lei russa de 1911, artigo 37 a 40 e a japonesa de 1.889, art. 30 ("Código Civil dos Estados Unidos do Brasil Comentado, v. III, Livraria Francisco Alves, Rio de Janeiro, 1917, p. 205).

12 Conforme a nota lateral $n^{\circ} 19$ (obra citada, $p$. 177) destacamos a decisão (de 1960), do Supremo Tribunal Federal referendando o "direito de citação" previsto no art. 666, I do Código Civil de 1916 : "Não se considera ofensa aos direitos de autor a reprodução de trecho de obra já publicada, em revista destinada a fim literário, didático ou religioso, desde que feita a indicação da origem e do nome do autor" (acórdão de 20/12/1960 proferido no recurso extraordinário 44.754, segunda Turma, relator o Ministro RIBEIRO DA COSTA -RTJ v. 16-01.p.172).

13 p. 180 .

14 Nos termos da nossa nota lateral n. 28 (obra citada, p. 180), conforme a Revisão de Paris, de 24.07.1971, com a modificação de 28.09.1979. A Convenção, na forma adquirida com o Ato de Paris (revisão) de 1971, foi formalmente adotada pelo direito positivo interno brasileiro de 1975 (anteriormente, portanto, à sua modificação de 1979) pelo Decreto Legislativo n. 94, de 04.12.1974 que a aprovou, seguido do Decreto 75.699, de 06.05.1975 que a promulgou. Tal modificação, contudo, não atingiu os textos originários da Convenção, na forma final da Revisão de Paris de 1971. 
- são lícitas as citações tiradas de uma obra já licitamente tornada acessível ao público, com a condição de que sejam conformes aos bons usos e na medida justificada (pela finalidade a ser atingida) inclusive as citações de artigos de jornais e coleções periódicos sob a forma de resumos de imprensa,

(b) em relação à finalidade de ensino :

- os países da União reservam-se a faculdade de regular, nas leis nacionais e acordos particulares já celebrados ou a celebrar entre si, as condições em que podem ser utilizadas licitamente, na medida justificada pelo fim a atingir, obras literárias ou artísticas a título de ilustração do ensino em publicações, emissões radiofônicas ou gravações sonoras ou visuais, sob a condição de que tal utilização seja conforme aos bons usos;

- as citações e utilizações referidas nos parágrafos antecedentes serão acompanhadas pela menção da fonte e do nome do autor, se esse nome figurar na fonte. ${ }^{15}$

\subsubsection{O regime legal brasileiro vigente}

Da mesma forma, retomamos a obra $\operatorname{citada}^{16}$ para ressaltar que as mesmas regras, bem como a finalidade científica, didática ou religiosa (e ainda de "crítica ou polêmica") para que uma obra intelectual nova pudesse utilizar obra anterior, conforme já previa o diploma regente de 1973, ${ }^{1718}$ foram reeditadas pela Lei n. 9.610, de 19.02.1998, ora vigente:

\section{Capítulo IV}

Das Limitações aos Direitos Autorais :

Art. 46. Não constitui ofensa aos direitos autorais :

(...)

III - A citação em livros, jornais, revistas ou qualquer outro meio de comunicação, de passagens de qualquer obra, para fins de estudo, crítica ou polêmica, na medida justificada para o fim a atingir, indicando-se o nome do autor e a origem da obra.

\footnotetext{
15 Conforme indicamos em nossa nota lateral n. 29 (obra citada, p. 180): Inciso " 3 " do art. 10 da Convenção de Berna e incisos "1" e "2" do mesmo artigo. Observe-se que na tradução para o português adotou-se no Decreto 75.699/75, a expressão "bons usos" para as expressões inglesas "fair use" ou "fair practice", a francesa "bons usages" e espanhola "usos honrados".

16 p.183.

17 Incisos I, alínea “a” e III do art. 49 da Lei n. 5.988, de 14.12.1973 (já citados).
} 
Assim, conjugou, a lei de direitos autorais vigente em um único inciso (III do art. 46) os anteriores I, "a" e VI da lei anterior, com, basicamente, as seguintes alterações :

(a) acrescentou-se a "livros, jornais e revistas" a expressão: "ou qualquer meio de comunicação";

(b) suprimiu-se, do rol das limitações aos direitos de autor, a previsão da reprodução de "pequenas composições alheias no contexto de obra maior"; e

(c) condicionou-se o permissivo legal da citação "de passagens de qualquer obra" à "medida justificada para o fim a atingir".

$\mathrm{O}$ regime legal brasileiro vigente quanto à permissão de uso - $e$, destarte, limitação de direito de autor - de obra preexistente em obra nova confere tratamento substancialmente diferenciado entre: (a) o direito de citação, propriamente dito que é o disposto no inciso III do art. 46 da Lei 9.610/98 (supra referido) e (b) o direito geral (de possibilidade lícita) de uso de obra preexistente por obra nova.

Essa distinção - entre o específico (direito de citação) e o genérico (direito geral de uso) - evidencia-se do simples confronto entre o dispositivo legal a que já nos referimos (art. 46, III da Lei n. 9.610/98), que regula o direito de citação e o inciso VIII do mesmo artigo (46), sobre o direito geral de uso de obra preexistente por obra nova, qual seja:

“Art. 46. Não constitui ofensa aos direitos autorais:

(...)

VIII - a reprodução, em quaisquer obras, de pequenos trechos de obras preexistentes, de qualquer natureza, ou de obra integral, quando de artes plásticas, sempre que a reprodução em si não seja objetivo principal de obra nova e que não prejudique a exploração normal da obra reproduzida nem cause um prejuízo injustificado aos legítimos interesses dos autores.

Portanto, resulta categoricamente da letra da nossa lei vigente para direito autoral, a diferença fundamental entre este - direito geral de uso - e direito de citação que consiste em, no primeiro caso, na regra de que tal uso - ou reprodução - em obra nova se limita a "pequenos trechos de obras preexistentes" (com exceção da reprodução de obra de artes plásticas" que pode ser integral) enquanto que no segundo caso (direito de citação regulado pelo inciso III do mesmo art. 46) não há essa limitação pois o permissivo legal respeita a "passagens de qualquer obra" (na medida justificada pra o fim a atingir) em razão, justamente, da finalidade da citação ser de "estudo, crítica ou polêmica") que, por sua relevância e amplitude, não pode, portanto, sujeitar-se à restrição do uso comum de "pequenos trechos", ainda mais no plano dos estudos de natureza científica acadêmica. 
1.3. Natureza jurídica do plágio e elementos caracterizadores dessa modalidade de ilícito

Preliminarmente, cumpre consignar no presente parecer que estudamos esse tema na obra "Direito Autoral no Brasil", tanto em sua primeira quanto em sua recente segunda edição (1998 e 2008, respectivamente).

Conseqüentemente, frente ao exame do caso concreto nesse campo - objeto deste trabalho - entendemos de rigor a reedição, neste item ("plágio") de textos pertinentes e conclusões doutrinárias que já havíamos lançado nesse obra publicada, a exemplo do que fizemos neste parecer em relação à abordagem anterior - também respeitante a nosso posicionamento já divulgado - sobre a localização da matéria no terreno constitucional e no tocante ao permissivo legal da citação de obras preexistentes em novas obras, para fins de estudo, crítica ou polêmica. ${ }^{18}$

Entre outros fatores, entendemos aconselhável a adoção desse critério expositivo para demonstrar que não há qualquer desvio de nossa linha de pensamento doutrinário para atendimento do caso concreto em exame, tendo em vista, inclusive, que trechos da nossa referida obra foram textualmente reproduzidos, como fundamento de acusação, no libelo em questão (p. 25, 27 e 28 do Recurso de 06.06.2008 ao Conselho Universitário da USP.

A partir desses esclarecimentos, voltamos à citação de "Direito Autoral no Brasil", ${ }^{19}$ na parte em que tratamos do "plágio", destacamos, inicialmente que "embora não haja dispositivos legais específicos no direito brasileiro, envolve matéria ("violação a direitos de autor" ${ }^{20}$ ) abrigada, sob aspecto genérico, na Constituição Federal (tanto no atual diploma, art. 5, inciso XXVII, quanto no anterior, art. 153, parágrafo 25), na legislação civil e penal ${ }^{21}$ e tanto a jurisprudência quanto a melhor doutrina aplicável considera o "plágio", além de sério ilícito civil, como verdadeiro crime. ${ }^{22}$

18 Itens "1.1. e 1.2" do presente parecer.

19 Embora todos os textos que utilizamos neste parecer tenham sido extraídos da sua segunda edição, publicada em 2008, mais atualizada, encontram-se estes em plena paridade e, mesmo, literalidade com os da primeira edição, de 1998 .

20 Hermano Duval sintetiza as violações de direito autoral em quatro modalidades: "a) igualdade de forma de expressão = contrafação total ou parcial; b) semelhança de tratamento sob a mesma forma de expressão = plágio; c) semelhança de tratamento sob diversa forma de expressão = plágio ou adaptação, e d) semelhança de tratamento e de forma de expressão por força do assunto tratado = obra nova independente". (Violações dos Direitos Autorais, Rio de Janeiro, Editor Borsoi, 1985, p. 122). A respeito da última modalidade, Duval cita o precursor jurista francês Eugène Pouillet para esclarecer que quando o assunto tratado em duas obras pertence à mesma natureza técnica e existe uma impossibilidade de redação diferenciada, não resultaria, a obra nova em contrafação da anterior (obra citada, p. 122, ainda).

21 Artigos 101 a 110 da Lei 9.610, de 19.02 .1998 (campo civil) e arts. 184 e 186 do Código Penal (estes conforme a redação da Lei 10.695, de 01.07.2003 que revogou o art. 185)

22 Obra citada, p. 319 e 320. 
Embora enquadre-se o plágio no âmbito genérico de "violação a direito de autor", ensina Antonio Chaves, que se trata de ilícito "mais sutil": "apresenta o trabalho alheio como próprio mediante o aproveitamento disfarçado, mascarado, diluído, obliquo, de frases, idéias, personagens, situações, roteiros e demais elementos das criações alheias". ${ }^{23}$

O plágio considerado por Zara Algardi como "um problema essencial" na área do direito de autor ${ }^{24}$ tem merecido tamanho repúdio entre os doutrinadores da matéria que, por exemplo, Dirceu de Oliveira e Silva chega a considerá-lo como possivelmente, "a modalidade de contrafação mais repulsiva" não só pelo furto intelectual, mas, principalmente pelo processo de dissimulação utilizado pelo plagiário. Em seguida, admite que, em tese, o plágio é de difícil verificação, "porque o plagiário procura sempre dissimular o seu crime, com a mudança do nome das personagens, com a introdução ou supressão de certos episódios, com a inversão na sucessão dos episódios, etc". ${ }^{25}$

Nesse sentido, reafirmamos ${ }^{26}$ que certamente o crime de plágio representa o tipo de usurpação intelectual mais repudiado por todos: por sua malícia, sua dissimulação, pela consciente e intencional má-fé do infrator em se apropriar - como se de sua autoria fosse - obra intelectual (normalmente já consagrada) que sabe não ser sua.

Destarte, para que advenha a condenação decorrente do plágio, não pode restar a mínima sombra de dúvida de sua prática efetiva, em toda a malícia e até vilania que tal crime representa.

No crime de plágio, a avaliação dos aspectos subjetivos, especialmente no que concerne à efetiva intenção do agente, é primordial. Trata-se de ação dolosa de usurpação (convenientemente "camuflada") da obra alheia.

\footnotetext{
23 "Plagio", artigo publicado na Revista de Informação Legislativa do Senado Federal a 20 n. 77, janeiro/março de 83, p. 406. É o próprio Antonio Chaves que em sua alentada obra "Criador da Obra Intelectual" (São Paulo, Editora LTR, 1995, pp.39 e 40) relata que, na Grécia antiga "o plágio era, sem dúvida, praticado e reconhecido, mas não encontrava outra sanção senão a verberação do prejudicado e a condenação da opinião pública" e complementa "Lembra György Boytha, que no século IV a..c. Platão se queixava de que fariam circular transcrições de seus discursos, na Sicília". Nessa mesma linha histórica Plínio Cabral se reporta à época romana, lembrando que mesmo que o autor fosse escravo - e, assim, pertencendo a obra ao seu senhor - a autoria e a "glória do feito" era do artista e acrescenta : "Essa característica pessoal é que levou, em Roma, a condenação pública dos plagiários, que eram execrados. A própria palavra já é, em si, uma condenação. Plagiarius significa sequestrador, aquele que rouba algo muito pessoal, como se fora um ser humano". (A Nova Lei de Direios Autorais, Porto Alegre, Editora Sagra Luzzatto, 1998, p. 13). (cf. consignamos em "Direito Autoral no Brasil", citada, p. 319).

24 "Il Plagio Letterario e Il caractere creativo dell'opera", editora Giuffrré, Milão, 1966,p. 191. (cf. nossa obra citada, p. 319 e 320).

25 "O Direito de Autor", Editora Nacional de Direito, Rio de Janeiro, 1956 , p. 64. (cf.nossa obra citada, p.319 e 320).

26 Obra citada, p. 320.
} 
Portanto, como já observamos, ${ }^{2728}$ o plágio consiste verdadeira fraude uma vez que esta, conforme ensina Plácido e Silva é o "engano malicioso" ou a "ação astuciosa" promovidos de má-fé e sempre se funda na prática de "ato lesivo a interesses de terceiros ou da coletividade". Conclui o insigne jurista:

A fraude, firma-se na evidência do prejuízo causado intencionalmente, pela oculta maquinação. ${ }^{28}$

Assim, a constatação da existência efetiva da intenção de plagiar é fundamental na avaliação do caso concreto, para alcançar o justo veredicto. A respeito, Edman Ayres de Abreu considera a intenção como um dos elementos fundamentais do plágio:

Versa (o plágio) sempre sobre as partes essenciais de uma obra ou as que imprimam originalidade e personalidade à obra. É a busca da validade artística e talento que o plagiador procura inescrupulosamente. ${ }^{29}$

A título de desfecho desse apanhado doutrinário sobre o ilícito de "plágio" cabe a transcrição das lições sobre o tema do próprio acusado, o jurista Professor Carlos Alberto Dabus Maluf no alentado "Curso de Direito Civil" (volume 3, Direito das Coisas, 39. ed., Editor Saraiva, São Paulo, 2009), do saudoso civilista, professor emérito da Faculdade de Direito da USP, Washington de Barros Monteiro, em edição que o Professor Dabus Maluf participa como co-autor, lições estas que sua pertinência ao caso em exame, transcrevemos a seguir, na íntegra:

A Lei n. 9.610/98, depois de estruturar a face positiva dos direitos autorais, passa em seguida, no art. 46, a traçar-lhes o aspecto negativo, discriminando os vários casos em que não há violação a esses mesmo direitos.

Assim, não se considera ofensa aos direitos do autor a reprodução de passagens ou trechos de obra já publicadas e a inserção, ainda que integral, de pequenas composições alheias no corpo de obra maior, contanto que esta apresente caráter científico, ou seja, compilação destinada a fim literário, didático ou religioso, indicando-se, porém, a origem de onde se tomaram os excertos, bem como o nome dos autores.

Nesses preceitos legais, o legislador prevê, portanto, o direito de citar obra alheia. Detesta ele, naturalmente, o plágio, que consiste na apresentação de textos, motivos, enredos ou personagens, criados por outrem, modificando-os

\footnotetext{
Obra citada, p. 321

"Vocabulário Jurídico", Rio de Janeiro, Editora Forense, 5. ed., 1961, p. 718.

"Obra citada, p. 124. (cf. nossa obra citada, p. 321).
} 
ou não, como se fossem de sua própria invenção (cf. Anatol Rosenfeld, O Estado de S. Paulo, de 15-8-1959, suplemento literário).

Ocorre o plágio quando a semelhança resulta de apropriação consciente de obra alheia ou de seus elementos integrantes, como fatos, conceitos, sentimentos, tema, sistema, método, estilo, forma literária, maneira artística, vocabulário lingüístico. A fraude se verifica quando a usurpação abrange um número apreciável ou sensível desses elementos (cf. Piola-Caselli, "Diritto di Autore", in Nuovo Digesto Italiano, n. 74).

Mas o plágio constitui matéria delicada, cujo reconhecimento demanda prova muito cuidadosa (cf.Revista dos Tribunais, 192/793-347/133; Revista Forense, 198/272). Com efeito, autores notáveis, que sempre desfrutaram da maior nomeada, não lograram subtrair-se à pecha de plagiários.

Assim, afirma Villenave (cf. "Oeuvres Complètes de Virgile, pág. 68) que os poetas da antiguidade, como Virgilio, eram cheios de imitações, que, hoje, passariam por plágios. De modo idêntico, diz-se de Shakespeare que muitos de seus versos foram transcritos e outros modificados. Só uma pequena parte seria exclusivamente original.

Aliás, escreve Somerset Maugham (Don Fernando, p. 22) que vê com indulgência semelhante delito, acrescentando que os escritores tomam o respectivo material de uma fonte ou de outra (je prends mon bien où je le trouve) e apenas reconhecem a sua dívida quando não têm outro remédio.

A lei não veda, entretanto, simples transcrição ou citação da obra de outrem, porquanto economicamente, não afetam o autor, antes valorizam-lhe a obra, contribuindo par sua maior difusão e acolhida

(a citação e a transcrição têm sido comparadas ao trabalho das abelhas junto às flores; no fundo, nenhum dano causam aos autores).

Mas, naturalmente, condiciona-se o direito de citação, ou de inserção de obra alheia, ao concurso de vários requisitos: a) os trechos citados devem apresentar, no conjunto da obra, papel secundário. Segundo sugestiva imagem de Sá Pereira (Direito das Coisas, p. 486), as transcrições devem enfeitar a obra como a renda ao vestido; b) a citação e a inserção de trabalho alheio admitem-se apenas em obras que apresentem caráter científico, didático ou religioso. Intolerável se torna a transcrição numa obra literária, num drama, numa poesia ou numa música (Não se beneficia da exceção aberta ao art. 663 pelo art. 666, n. I do Código Civil de 1916 aquele que se limita a editar compilação de escritos alheios, desacompanhada de notas ou comentários, para que possa ser tida como obra no sentido legal (Ver. dos Trib., 317/437); c) por último, quem fizer a citação, inserção ou 
transcrição deve indicar escrupulosamente as fontes, assim como os nomes dos autores. ${ }^{30}$

2. O caso concreto: aspectos genéricos

2.1. Preliminarmente: fundamentos relativos à matéria relevantes à hipótese em exame

A partir do exposto até aqui, fica claro que o esclarecimento das questões em análise surgirá da cuidadosa avaliação quanto ao correto enquadramento das objeções levantadas pela acusação às hipóteses de: ato ilícito de plágio, de um lado, ou exercício regular do direito de citação, do outro.

Assim, se o caso em exame se inserir no terreno lícito do exercício regular do direito de citação, ou seja, se restar caracterizada a citação, pelo autor da obra questionada, de "passagens" de obras preexistentes "na medida justificada para o fim a atingir, indicando-se o nome do autor e a origem da obra", ${ }^{31}$ estará afastada a censura objeto do recurso administrativo em tela.

Todavia, se - ao contrário - for justificada na hipótese vertente a prática do crime de plágio, restará procedente a acusação, com as cominações de direito.

\subsubsection{Requisitos para a avaliação da existência de plágio}

Nesse campo, entendemos que a hipótese que conduz à ilicitude da obra criticada - com a caracterização do plágio - deverá ser apreciada inicialmente frente a dois elementos de natureza genérica:

(a) a qualificação do autor questionado: uma vez que o plágio consiste no artifício malicioso de um pseudo autor, ou seja, aproveitamento de obra de outros dar-se-ia em razão de o agente do crime não possuir a qualificação intelectual (artística ou científica) indispensável à realização da obra objeto da crítica; ${ }^{32} \mathrm{e}$

\footnotetext{
Obra citada, pp. 525 e 526.

Art. 46, III da Lei 9.610/98.

32 Consoante leciona Edman Ayres de Abreu: "É a busca da validade artística e talento que o plagiador procura inescrupolosamente" (conforme citamos na p. 17 do presente). Esse aspecto foi fundamental, por exemplo, no deslinde judicial (reivindicação de autoria de obra musical) pelo Tribunal de Justiça de São Paulo: em acórdão de 29.08.2007, proferido na Apelação Cível com Revisão n. 405.075 - 4/9 - 00, por unanimidade de sua Sétima Câmara de Direito Privado (relator o Desembargador Gilberto de Souza Moreira) restou evidenciada a inadequação de qualificação ao pretenso autor de obra musical demandante que inviabilizaria, assim, sua pretensão indenizatória por alegada violação de direito autoral. Interessante a transcrição de parte da motivação dessa decisão: "O privilegiado artista que se imaginou, todavia, decepciona ao apresentar-se no processo em depoimento pessoal. Ao subir ao palco não revelou o talento anunciado e esperado. $\mathrm{Na}$
} 
(b) a qualificação da obra questionada: se a obra acusada de plágio possui os requisitos de originalidade e ineditismo próprios à caracterização de obra intelectual originária ou, se, ao contrário, não contém autonomia estéticointelectual não sobrevivendo, neste caso, como obra intelectual íntegra, caso lhe seja retirado o aproveitamento de obras preexistentes (de terceiros) que tenha incorporado.

A partir da resposta - caso positiva - a esses dois elementos de natureza genérica, ou seja, se há qualificação do autor e da obra questionada, passar-se-á à etapa seguinte de avaliação, qual seja, no plano específico: se os aproveitamentos inseridos na obra nova ( a monografia questionada) de obras preexistentes enquadram-se na hipótese de plágio em razão de:

(a) omissão, pelo autor questionado, da verdadeira autoria das obras utilizadas, e

(b) dissimulação, pelo autor questionado, de partes identificativas, essenciais da obra aproveitada, ${ }^{33}$ de forma a dar a impressão de que se trata de obra de sua autoria (do plagiador), apresentando, portanto, "trabalho alheio como próprio" 34 - caracterização de fraude, entendida esta como "engano malicioso" ou "ação astuciosa" promovidos de má-fé e que sempre se funda na prática de "ato lesivo a interesse de terceiros ou da coletividade". ${ }_{3536}$

2.1.2. Requisitos para avaliação da regularidade da citação, em obra nova, de obras preexistentes

Concomitantemente com o exame dos requisitos que mencionamos, atribuíveis à caracterização do plágio, adequado - para a hipótese vertente - a apreciação

verdade, nem mesmo é músico, jamais compôs qualquer obra musical, ao que parece não sabe distinguir a

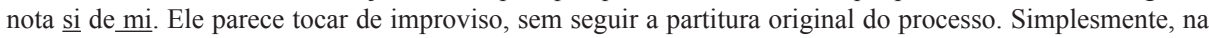
qualidade de publicitário e de empresário, sócio da agência autora, pretende merecer crédito pela autoria da obra porque sua equipe de trabalho, não ele solista, teria criado a melodia e a música, quando se desenvolvia uma campanha para a marca de chinelos Rider" (Acórdão citado, p. 3).

33 Conforme a assertiva, ainda, de Edman Ayres de Abreu (que citamos na p. 17 do presente): "Versa (o plágio) sempre sobre as partes essenciais de uma obra ou as que imprimam originalidade e personalidade à obra".

34 Conforme a lição de Antonio Chaves que citamos na p. 14 do presente: "(o autor do plágio) apresenta o trabalho alheio como próprio mediante o aproveitamento disfarçado, mascarado, diluído, oblíquo de frases, idéias, personagens, situações, roteiros e demais elementos de criação alheias". Essa "dissimulação" é, também, destacada como elemento primordial do plágio por Dirceu de Oliveira e Silva (como já referimos nas p. 14-15 do presente), "porque o plagiário procura sempre dissimular o seu crime, com a mudança do nome dos personagens, com a introdução ou supressão de certos episódios, com a inversão na sucessão dos episódios, etc".

35 Conforme a doutrina de Plácido e Silva que citamos na p. 16 do presente: "A fraude, firma-se na evidência do prejuízo causado intencionalmente, pela oculta maquinação". 
quanto à regularidade do exercício, pelo autor questionado, do direito de citação, em sua obra, de obras preexistentes, o que consubstanciaria a licitude do seu procedimento. ${ }^{36}$

Nesse caminho, destacamos, a seguir, os principais requisitos do direito de citação:

(a) sob o aspecto genérico: o enquadramento da obra questionada quanto à sua finalidade : de estudo, crítica ou polêmica; ${ }^{37}$

(b) sob o aspecto específico:

(b.1) a adequação da citação de obras preexistentes a "passagens" desta "na medida justificada para o fim a atingir", ${ }^{38} \mathrm{e}$

(b.2) a indicação do nome do autor e a origem da obra citada. ${ }^{3940}$

\subsection{A aplicabilidade desses fundamentos ao caso concreto, sob o aspecto genérico}

\subsubsection{Considerações sobre os requisitos (genéricos) do plágio frente ao caso concreto}

\subsubsection{Primeiro requisito (genérico): a qualificação do autor questionado}

É indiscutível a efetiva qualificação intelectual científica do autor questionado, Carlos Alberto Dabus Maluf, renomado jurista e professor universitário há quase três décadas, como se depreende, entre outras que poderiam ser destacadas de seu notório extenso "curriculum" profissional e acadêmico, das suas seguintes obras e realizações:

(a) Advogado militante na alçada civil há mais de trinta e cinco anos, desde 1971;

(b) Indicado por duas vezes para compor um dos nossos Tribunais de Alçada Civil pelo quinto constitucional dos advogados, no ano de 1991;

(c) Advogado da Light/Eletropaulo S/A, por mais de vinte anos, onde foi inclusive chefe da divisão de desapropriação e

36 Essa licitude - conforme já nos referimos nas pp. 3 a 6 do presente - deverá ser examinada, naturalmente, no contexto da garantia constitucional conferida ao autor questionado quanto à as liberdade de expressão de seu pensamento e de sua "atividade intelectual, artística, científica e de comunicação, independentemente de censura ou licença" (incisos IV e IX do art. $5^{\circ}$ da Carta Magna).

37 Nos termos do inciso III do art. 46 da Lei 9.610/98 (transcrito na p. 10 do presente) que estabelece não constituir ofensa aos direitos autorais a citação de passagens de qualquer obra em livros, jornais, revistas ou qualquer outro meio de comunicação "para fins de estudo, crítica ou polêmica".

38 Conforme, ainda, o inciso III do art. 46 da Lei 9.610/98. Vide também sobre o tema as considerações que expusemos às pp. 9 a 11 do presente.

39 Idem. 
registro, no período de 1977 e 1997, quando aposentou-se.

(d) ATIVIDADES ACADÊMICAS.

(d.1) Bacharel em Direito pela Faculdade de Direito da Universidade de São Paulo, Turma de 1970;

(d.2) Mestre pela Faculdade de Direito da Universidade de São Paulo, em 1979, tendo apresentado a dissertação intitulada "Cláusulas restritivas nas doações e nos testamentos", tendo como orientador o Professor Catedrático Silvio Rogrigues;

(d.3) Doutor em Direito pela Faculdade de Direito da Universidade de São Paulo, em 1988, tendo apresentado a tese “ A transação no direito civil", tendo como orientador o Professor Titular Yussef Said Cahali;

(d.4) Livre Docente de Direito Civil, também pela Faculdade de Direito da Universidade de São Paulo, em 1988, tendo apresentado a tese " $O$ condomínio tradicional no direito civil";

(d.5) Professor Assistente no período de 1981 a 1988, tendo ingressado na carreira de professor de Direito da Universidade de São Paulo, por meio de concurso público de provas e títulos em 1980;

(d.6) Professor Associado da Faculdade de Direito da Universidade de São Paulo, no período de 1988 a 2007;

(d.7) Professor Titular de Direito Civil da Faculdade de Direito da Universidade de São Paulo, por concurso de provas e títulos, a partir de fevereiro de 2008 , tendo apresentado a tese " $A$ inexistência na teoria das nulidades", pela Faculdade de Direito da Universidade de São Paulo;

(e) Conselheiro do Instituto dos Advogados de São Paulo, desde 2002;

(f) É colaborador de inúmeras revistas jurídicas (Revista dos Tribunais, Revista Forense, Revista de Processo e Revista de Direito Civil), do Jornal Tribuna do Direito, do Jornal do Advogado, do Boletim do Direito Imobiliário, desde 1975 e do Jornal O ESTADO DE SÃO PAULO, onde publicou 11 artigos no período de 1990 a 1992;

(g) Membro da comissão constituída pelo Deputado Ricardo 
Fiuza para apresentar críticas e sugestões visando o aperfeiçoamento do Novo Código Civil de 2002, desde 2001.

(h) Autor das seguintes monografias:

(h.1) Das cláusulas de inalienabilidade, incomunicabilidade e impenhorabilidade, 1. ed. - 1981, 2. ed. - 1983, 3. ed. - 1986, todas pela Editora Saraiva e 4. ed. - 2006, pela Revista dos Tribunais;

(h.2) As condições no direito civil, 1. ed. - 1983, pela Editora Forense, 2. ed. - 1991, pela Editora Saraiva;

(h.3) A transação no direito civil, 1. ed. - 1985 e 2. ed. - 1999, Editora Saraiva;

(h.4) Ação de Desapropriação, Saraiva, 1985 (Col. Saraiva de Prática do Direito);

(h.5) Ação de extinção de condomínio, Saraiva, 1986 (Col. Saraiva de Prática do Direito).

(h.6) O condomínio tradicional no direito civil, 1. ed. - 1988, Editora Loyola, 2. edi. - 1989, Editora Saraiva.

(h.7) Comentários à lei de locação de imóveis urbanos (artigos 22 a 26 e 37 a 42 da Lei n. 8245), Editora Saraiva, 1992, obra coletiva, coordenação Juarez de Oliveira;

(h.8) Teoria e prática da desapropriação, 1. ed. - 1995, 2. ed. - 1999, ambas pela Editora Saraiva 1999;

(h.9) Limitações ao Direito de Propriedade, 1. ed. - 1997, Editora Saraiva, 2. ed. atual. - 2005, Editora Revista dos Tribunais;

(h.10) Código Civil Comentado, 1. ed. - 2002, 2. e 3. ed. 2004, 4. ed. -2005 , 5. ed. -2006 e 6. ed. -2008 , todas pela Editora Saraiva - obra coletiva, coordenação: 1. e 5. ed., Ricardo Fiuza e 6. ed., Regina Beatriz Tavares da Silva;

(h.11) Curso de Direito Civil - Direito das Coisas - Washington de Barros Monteiro e Carlos Alberto Dabus Maluf - 37. ed. - 2003 e 38. ed. - 2007, como atualizador e 39. ed., rev., atual. e ampl. - 2009, como co-autor - todas pela Editora Saraiva;

(h.12) Curso de Direito Civil - Direito das Obrigações - Parte Geral - Washington de Barros Monteiro e Carlos Alberto Dabus Maluf - 32. ed. - 2003 e 34. ed. - 2007, como atual. e 34. ed. - 2009, revista, atualizada e ampliada como co autor, 
todas pela Editora Saraiva;

(h.13) Curso de Direito Civil - Direito das Obrigações - Contratos e Atos Unilaterais e Responsabilidade Civil - Washington de Barros Monteiro, Carlos Alberto Dabus Maluf e Regina Beatriz Tavares Da Silva - 34. ed. - 2003 e 35. ed. - 2007, como atualizadores e 36 . ed. - 2009, revista, atualizada e ampliada, como co-autores, todas pela Editora Saraiva.

(h.14) Questões Controvertidas no Novo Código Civil, Editora Método, v. 1 - 2003, v. V - 2006 e v. VII - 2008 - obra coletiva, coordenação: Jones Figueirêdo Alves, e Mario Luiz Delgado

(h.15) O Condomínio Edifício no Novo Código Civil, 1. ed. - 2004, 2. ed. -2005 e 2. tir. da 2. ed. - 2006, atualizada, todas pela Editora Saraiva, em co- autoria com Marcio Antero Motta Ramos Marques, e

(h.16) Prescrição, Decadência e Prova. Comentários ao Código Civil. v. III, Editora Atlas, 2009, coordenação Álvaro Villaça Azevedo.

Conseqüentemente, inafastável a conclusão quanto à sua elevada qualificação intelectual, científica e jurídica, para a elaboração da monografia em questão, sem qualquer necessidade de buscar - como é próprio, como já vimos, da prática "inescrupulosa" do plagiador - validade intelectual e científica na obra de terceiros. ${ }^{40}$

\subsubsection{Segundo requisito (genérico): a qualificação da obra questionada}

Resta evidenciado, da mesma forma, o alto nível de qualificação científica e de autonomia estético-intelectual da monografia " A Inexistência na Teoria das Nulidades" de Carlos Alberto Dabus Maluf, especialmente em suas características de ineditismo e originalidade, tanto no aspecto de pesquisa, quanto no de desenvolvimento, estruturação e conclusões próprias.

Com efeito, lançada em 202 páginas - com referências bibliográficas de quase 200 obras, nacionais e estrangeiras - trata-se de obra pioneira e inédita no Brasil. Não existe nenhuma monografia sobre esse tema. A originalidade desse trabalho consiste em fazer a diferenciação entre o ato inexistente e o nulo. A importância desse tema é fundamental porque, conforme exposto o jurista em questão, enquanto o ato inexistente

40 Conforme a orientação, a que já nos referimos, de Edman Ayres de Abreu.(p. 17 do presente). 
não prescreve e não convalida tal não se dá com o ato nulo, onde pode ocorrer a prescrição e a convalidação.

A tese consigna relevante histórico desde a origem da inexistência do negócio jurídico passando pelo direito romano, direito medieval, direito costumeiro francês e pelo antigo direito luso-brasileiro e cuida dos caracteres do ato inexistente, realizando um estudo principalmente na doutrina francesa, na doutrina italiana, na doutrina espanhola, na doutrina argentina e na doutrina brasileira.

Entre outros temas de inegável pertinência, a obra do casamento inexistente, dos contratos inexistentes e do testamento inexistente e ainda, dos atos inexistentes no processo e das sentenças inexistentes.

Nesse caminho, com evidente aplicabilidade a termos da atualidade, seu posicionamento dirige-se à aceitação da teoria da inexistência, defendendo ser a única apta à solução de resolver certas questões, como por exemplo, o casamento de pessoas do mesmo sexo e a venda e compra sem preço ou sem objeto. Leciona o jurista que, nessas hipóteses só poderá haver uma sentença declaratória de inexistência, nunca de nulidade em razão de a inexistência encontrar-se situada num plano diferente da nulidade.

Manifesta, o jurista, sua discordância daqueles autores que não fazem a distinção entre a inexistência e nulidade absoluta, mesmo porque, conceitualmente, destaca uma nítida distinção entre ambas. Enquanto a primeira é um nada jurídico, a segunda existe, porém com vício que fulmina sua validade. ${ }^{41}$

Enfim, a qualificação intelectual-científica da monografia questionada é irrefutável tendo em vista, inclusive, que trata-se de tese jurídica - essencialmente em razão de suas características de originalidade e ineditismo, como é exigido no campo das teses acadêmicas - avaliada e julgada merecedora - para o mais alto cargo acadêmico no campo do direito civil da prestigiosa Universidade de São Paulo: a titularidade do respectivo departamento - pela maioria dos integrantes de sua banca examinadora integrada por respeitados e experientes juristas e professores, mediante, especificamente,

41 No contexto da complexidade do estudo do tema, posiciona-se o jurista questionando no sentido de que os atos de inexistência, por terem apenas a aparência jurídica nunca poderão ser objeto de convalidação, tampouco sujeitos a qualquer prescrição e que o ato nulo pode se converter em outro negócio válido, o que não ocorre com o inexistente. Ressalta também que o negócio nulo tem o suporte fático, que é a declaração de vontade, embora com irregularidade, enquanto no negócio inexistente não há a declaração de vontade, mas apenas uma aparência de vontade. Defende a "teoria da inexistência" porque muito embora reconheça que $\mathrm{o}$ ato inexistente não entra no mundo jurídico, por ser um fato, pondera o jurista que ele muitas vezes surte efeito na órbita do direito, como por exemplo, no caso de falsidade de um documento particular de venda e compra registrado : o ato é inexistente porque não houve manifestação de vontade e deverá ser desconstituído judicialmente, uma vez comprovada a falsidade através do laudo grafotécnico. 
os votos majoritários dos consagrados juristas Álvaro Villaça de Azevedo ${ }^{42}$ (nota 9.30), Rui Geraldo Camargo Viana ${ }^{43}$ (nota 9.06) e Ricardo César Pereira Lima ${ }^{44}$ (nota 8.90).

2.2.2. Considerações sobre o requisito (genérico) do direito de citação

Neste tema, o único requisito de natureza genérica que destacamos reside na seguinte questão: - para a devida adequação da limitação a direito autoral estabelecida no inciso III do art. 46 da Lei n. 9.610/98. teria a monografia questionada finalidade de "estudo, crítica ou polêmica"?

A resposta, obviamente - pelo que examinamos até aqui ${ }^{45}$ - só pode ser positiva, uma vez que é essência da tese acadêmica o "estudo" da matéria tratada, muitas vezes trazendo, também, uma vertente crítica - e até polêmica - em relação à obras ou posições doutrinárias já existentes. ${ }^{46}$

3. Os Aspectos Específicos da Hipótese em Tela : Exame das Questões Levantadas em Detrimento à Monografia "A Inexistência na Teoria das Nulidades"

A partir das considerações que já consignamos no âmbito genérico, passaremos, nesta etapa deste nosso estudo, à verificação específica - frente a cada uma das acusações levantadas contra a monografia em questão:

(a) no tocante às acusações de plágio:

se foi praticada, pelo autor questionado, omissão quanto à indicação da (verdadeira) autoria das obras preexistentes utilizadas, ou

- se houve, pelo autor questionado, dissimulação de pontos identificativos essenciais das obras aproveitadas, de forma a gerar a impressão de ser própria a obra de terceiros, e

(b) quanto ao regular exercício do direito de citação :

42 Professor Titular de Direito Civil da Universidade de São Paulo.

43 Professor Titular de Direito Civil da Universidade de São Paulo.

44 Professor da Faculdade de Direito da Universidade do Estado do Rio de Janeiro (UERJ)

45 Vide, especialmente, o item anterior do presente (2.2.1.2.-pp. 27 a 30), sobre a qualificação da obra questionada.

46 Nesse sentido categórico o acórdão do Tribunal de Justiça de São Paulo de 13.02.2008, proferido na Apelação Cível com Revisão no 464.316-4/1-00. por unanimidade de sua Oitava Câmara de Direito Privado, relator o Desembargador Caetano Lagrasta : “(...) em se tratando de base para uma ciência ou para uma tese, deles não se pode apropriar, caso contrário, um livro de civilista poderia ser alcunhado de plágio ao se abeberar em Clóvis Bevilaqua ou Pontes de Miranda e, assim vai."(parte de motivação do acórdão citado, p. 2 e 3). Vide a respeito as considerações que expusemos sobre o tratamento legal brasileiro vigente sobre este aspecto nas p. 10 a 12 do presente. 
se houve a adequação da citação de obras preexistentes a "passagens" desta " na medida justificada para o fim a atingir", e

- se houve indicação do nome do autor e a origem da obra citada.

Nessa linha, passemos às acusações formuladas no recurso administrativo em questão.

3.1. Proporcionalidade dos trechos impugnados em relação ao corpo integral da monografia questionada: partes não objetadas

As objeções à monografia foram inseridas nos autos do recurso em questão em dois momentos (a) no requerimento inicial de 06.06.2008 e (b) na manifestação do Professor José Rogério Cruz e Tucci de 20.03.2009:

(a) as objeções consignadas no recurso (requerimento inicial) de 06.06.2008 constam das seguintes páginas: 1. - p. $1 ; 2$ - p. $4-7 ; 3$. - p. $23-25 ; 4$ - p. $37-42: 475$ - p. $69-$ 76 ; 6 - p. 147 e 148.

(b) a manifestação de 20.03.2009 - parcialmente divergente $e^{48}$ - do membro da Comissão de Sindicância, Professor José Rogério Cruz e Tucci:

- acrescenta aos trechos consignados no recurso inaugural os constantes das seguintes páginas:

1. - p. 14; 2.- p. 19-22 ; 3 - p.77-80: 4. p.121-124; 5. p.156-158

6. - p. $175-179 ; 7 .-$ p. $180-187$

47 Registre-se que, neste item, há nos autos do processo administrativo manifestação de 23.07.2008 dos filhos do jurista Paulo Barbosa de Campos Filho, representados por sua advogada Angela M. Teixeira Leite Pacheco Di Francesco endossando a acusação em relação à parte respeitante a 3 páginas, quais sejam, as páginas 37 a 39 da monografia em exame.

48 Cabe observar que apesar de o Professor José Rogério Cruz e Tucci denominar sua manifestação de 20.03.2009, como membro da Comissão de Sindicância da USP, como "parcialmente divergente" (sic), apresentou, na verdade, inovação ao rol de acusações especificadas na petição inicial do recurso administrativo de 06.06.2008 (acrescentando várias novas objeções), resultando, dessa forma, na prática, em complementação (ou aditamento) do libelo acusatório primígeno. Destarte, para que nosso exame seja completo, optamos por reunir em um só Capítulo(de n. 3 - p. 32 a 66 do presente) todas as objeções que compõe a íntegra do corpo acusatório. 
Conseqüentemente, mesmo com as várias objeções adicionais inseridas pelo Professor Cruz e Tucci do requerimento inaugural, observa-se que:

(a) as objeções se adstringem, essencialmente, à parcela da tese respeitante à pesquisa, $\mathrm{e}$

(b) as objeções encontram-se em cerca de $25 \%$ (ou seja $1 / 4$ ) da totalidade das páginas da monografia em questão.

Destarte, nítida a conclusão preliminar de que:

(a) não há objeções quanto à originalidade e ineditismo das conclusões do autor questionado, e

(b) a monografia não é objeto de crítica em relação a $\underline{75 \% \text { (ou }}$ seja, 3/4) do seu conteúdo.

Assim, cabe concluirmos, ainda a título preliminar, que mesmo que fossem subtraídos os trechos impugnados constantes das páginas referidas - e mesmo considerando-se tais páginas de forma integral - subsistiria a monografia em relação aos 3/4 não objetados, tanto na parcela correspondente à pesquisa quanto ao seu conteúdo conclusivo.

\subsection{Exame das objeções lançadas à monografia em questão}

A partir de todas as ressalvas que consignamos até o momento, passemos ao exame específico de cada objeção formulada em detrimento da monografia " $A$ Inexistência na Teoria das Nulidades", de autoria do Professor Carlos Alberto Dabus Maluf, considerando - em relação a cada uma - como já expressamos, o seguinte:

(a) no tocante às acusações de plágio:

- $\quad$ se foi praticada, pelo autor questionado, omissão quanto à indicação da (verdadeira) autoria das obras preexistentes utilizadas, ou

- $\quad$ se houve, pelo autor questionado, dissimulação de pontos identificativos essenciais das obras aproveitadas, de forma a gerar a impressão de ser própria a obra de terceiros, e

(b) quanto ao regular exercício do direito de citação : se houve a adequação da citação de obras preexistentes a "passagens" desta "na medida justificada para o fim a atingir", e

- $\quad$ se houve indicação do nome do Autor e a origem da obra citada. 


\subsubsection{Capítulo 1: introdução}

Das 3 páginas integrantes deste capítulo $\left(\begin{array}{lll}p & 1 & a\end{array}\right)$ há objeção em relação à nota de rodapé inserida na p. 1 , nos seguintes termos :

As "coincidências começam, em verdade, já na primeira nota de rodapé de página 1 da tese do candidato. Assim está: "Diz Antonio Junqueira de Azevedo que "se chamássemos ao negócio jurídico inexistente, negócio jurídico aparente, evitaríamos inúteis discussões terminológicas", in Negócio jurídico e declaração negocial: noções gerais e formação da declaração negocial. 1986, p. 96 Tese (Titular) - Faculdade de Direito - Universidade de São Paulo. São muitos os autores que apontam a contraditio in terminis que há na expressão "negócio jurídico inexistente", entre os quais Jose Luiz de los Mozos, La inexistência del negôcio jurídico, Revista General de Legislación y Jurisprudência, Madrid, p. 38, abr. 1960 e Miguel Reale, Revogacão e anulamento do ato administrativo. Rio de Janeiro: Forense, 1968. p. 62. Para Sílvio de Salvo Venosa, a denominacão ato inexistente é, sem dúvida, ambígua e contraditória, pois o que não existe não pode ser considerado "ato" (Direito Civil: parte geral. São Paulo: Atlas, 2001. p. 478).

Ocorre que, na obra em questão (doc. 5), a nota de roda-pé redigida pelo Prof. Titular Antônio Junqueira Azevedo assim dispõe "se chamássemos ao negócio jurídico inexistente, negócio jurídico aparente, evitaríamos inúteis discussões terminológicas. São muitos os autores que apontam a contraditio in terminis que há na expressão 'negócio jurídico inexistente', entre os quais De Los Mozos (La inexistência, pág. 38) e Reale ("Revogação e Anulamento" pag. 62)".

Nessa observação, fica claro que, para o examinador do condidato (como pra qualquer leitor), houve a consulta dele - Dr. Dabus Maluf - à obra

de "De Los Mozos" e "Reale" quando, em verdade essa perquisa aos originais aparenta ter sido feita pela fonte". 49 (destaques próprios).

Entendemos improcedente a objeção pois: (a) não há plágio pois há a textual indicação do autor da obra citada e não houve dissimulação de pontos identificativos essenciais da obra utilizada e (b) foi praticado, pelo autor questionado, o regular exercício

${ }_{49}$ p. 5 do recurso, destaques e grifos próprios. 
de direito de citação de passagens da obra preexistente, na medida justificada para o fim a atingir, conforme a finalidade analítica-científica da monografia exminada, com expressa indicação do nome do seu autor e a origem da obra citada, consignada de forma completa.

Em complemento, cabe observar que o renomado jurista citado, Professor Antonio Junqueira de Azevedo, apenas faz menção a Reale e de Los Mozos, sendo que na citação do autor questionado, encontra-se consignado não somente o nome completo desses juristas mas também, a fonte, de forma completa: obras, editores, ano de publicação e página, ${ }^{50}$ o que comprova o efetivo acesso e consulta do Professor Dabus Maluf a essas obras, complementando s informações relativas à pesquisa. Registre-se, também, que além desse fato o autor questionado cita Silvio de Salvo Venosa, ${ }^{51}$ jurista não mencionado pelo Professor Junqueira.

\subsubsection{Capítulo 2: teoria das nulidades e os planos do negócio jurídicos}

Das 6 páginas integrantes deste capítulo $(p .4 a 9)$ há objeção em relação a 4 páginas ( $p .4$ a 7 ) nos seguintes termos :

(a) primeira objeção:

Nas páginas 4 a 7 da tese do candidato, até a indicação da nota de rodapé n. 10, outras "coincidências textuais" são de fácil verificação.

Do primeiro parágrafo da página 4 ao segundo parágrafo da página 5 , há a transcrição literal da obra de MARCOS BERNARDES DE MELLO. Observe-se o quadro comparativo.

(...)

A comparação dos dois excertos evidencia alguns pontos que merecem reflexão. Começa-se pelo início do excerto de DABUS MALUF. Diz ele que "Advertem Bevilágua 1 e Marcos Bernardes de Mello 2 que desde Domat...". Entretanto, como um texto é praticamente cópia de BERNARDES DE MELLO, aparentemente CLÓVIS nõ advertiu nada disso, não se sabendo precisar a razão da citação do nome do autor do antigo codex, abrindo-se a possibilidade de aplicação fraudulenta de citação, a ser melhor explicada pelo candidato.

\footnotetext{
50 REALE, Miguel. Revogação e anulamento do ato administrativo. Rio de Janeiro: Forense, 1968. p. 62 e LOS MOZOS, José Luis de. La inexistencia del negocio jurídico. Revista General de Legislacion y Jurisprudencia, Madrid, p. 38, abr. 1960.

51 Direito Civil: parte geral. São Paulo: 2001, p. 478.
} 
O texto, comparado com outro, ilustra que algumas alterações de redação foram feitas: a expressão original “instituição jurídica respectiva" foi aplicada em seu plural, sem explicação para a alteração do sentido entre uma expressão e outra; a expressão original "criam $\boldsymbol{a}$ impossibilidade de serem tracadas" foi "transformada" em "impossibilitaram tracarem-se"; a expressão original "Loix civile" foi "transformada" em "Lois Civiles" (aliás, ambas erradas); e há a criação de um parágrafo inexplicável.

Porém, o que realmente intriga são as notas de rodapé entre uma e outra obra.

A nota de BERNARDES DE MELLO de $\mathrm{n}^{\circ} 19$ parece corresponder a de $\mathrm{n}^{\circ} 3$ da obra do candidato. Porém, a primeira nota (a de $\mathrm{n}^{\circ} 19$, de Mello) faz referência a todos esses autores: Planiol ("Traité élémentaire de droit civile"), Zannoni ("Ineficacia y nulidad de los actos jurídicos"), Cifuntes ("Negocio Juridico”), Llambías ("Efectos de La nulidad i la anulacion de los actos jurídicos"), Lloveras de Resk (“Tratado Teórico-prático de las nulidades"), Fedele ("La invaliditá de negozio giuridico di diritto privato"), Gugghenreim ("L'invalidité dês actes juridiques em droit suisse et comparé") e Simler ("La nullité partielle des actes juridiques”), entre outros. Já a nota de DABUS MALUF trouxe a nota $\mathrm{n}^{\mathrm{o}} 3$ (que se refere ao mesmo texto, conceito e idéia da nota $\mathrm{n}^{\circ}$ 19: "Eduardo A. Zannoni, Ineficacia y nulidad de los actos jurídicos, Buenos Aires: Astrea, 1.986, p. 1; Santos Cifuntes, Negócio Jurídico. Buenos Aires; Astrea, 1986, p. 572; Daniel Gugghenreim, L'invalidité dês actes juridiques em droit Suisse et Compare: essai d'une theorie générale. Paris, LGDJ, 1970, p. 63 e ss.".

Aparentemente, o candidato não realizou a investigacão científica que quís sugerir ao leitor e ao seu examinador, transparecendo a falsa idéia de que a "sua pesquisa" resultou nessas referências. Mas essa "pesquisa" não seria um trabalho atribuído ao BERNARDES DE MELLO? É muito possível que sim!

Analogamente, a nota de BERNARDES DE MELLO n ${ }^{\circ} 20$ parece corresponder a de $n^{\circ} 4$, da obra do candidato. Porém o candidato aponta a obra de BERNARDES DE MELLO e esse, por sua vez, aponta o entendimento de LLAMBÍAS. Essa anotação é importante porque, em verdade, não há correção metodológica, já que o pensamento não é de Mello, mas de Llambías, e a obra do candidato não faz menção alguma ao REAL autor do pensamento. Esse não parece ser um critério cientificamente honesto. 
De modo semelhante, a nota de BERNARDES DE MELLO de $\mathrm{n}^{\circ} 21$ parece corresponder a de $\mathrm{n}^{\circ} 5$, da obra do candidato. Assim se refere DABUS MALUF : "5Marcos Bernardes de Mello, Teoria do Fato jurídico : plano de validade...cit. p. 13, diz na nota de rodapé n. 21 : Sobre a prática impossibilidade de elaboração de uma teoria geral das nulidades é necessário destacar a obra de René Japioto, Dês nullités em matière d'actes juridiques : essai d'une théorie nouvelle, Paris: A. Rosseau, 1909; Valle Ferreira, (Subsídios para o estudo das nulidades, Revista da Faculdade de Direito da UFMG, de Belo Horizonte, v. 3, p. 29 e ss. E Revista dos Tribunais, São Paulo, v. 341, p. 26) chama a atenção para as divergências terminológicas e metodológicas como causas das dificuldades no trato da matéria".

Além de a nota original de $\mathrm{n}^{\circ} 21$ ser muito mais extensa, Bernardes de Mello também cita para esse mesmo texto outros autores - todos omitidos por Maluf - consagrados : Aubry e Rau, Planiol, Guggenheim. E Valle Ferreira é também citado por Mello. Assim, nada de original tem a "pesquisa" do candidato e a omissão de autores para uma mesma redação configura omissão de dado que se reputa relevante.

Por fim, a nota de BERNARDES DE MELLO de $n^{\circ} 22$ parece corresponder a de $n^{\circ} 6$, da obra do candidato. É o mesmo problema anterior; o candidato omite que, em verdade, o pensamento original é tirado de interpretação de Aubrey e Rau.” (destaques próprios).

(b) - segunda objeção:

"Na mesma página 5 da obra do candidato, termina no $2^{\circ}$ parágrafo a "citação" de MARCOS BERNARDES DE MELLO inicia-se FRANCISCO AMARAL. Novamente, o quadro comparativo que muito elucida uma e outra obra:

Anote-se que o candidato, nesse excerto, aproveita-se de 5 (cinco) parágrafos da obra de Amaral. Porém, atribui 4 (quatro) deles à fonte.

Além disso, a nota de rodapé $n^{\circ} 3$ de Amaral faz menção a ORLANDO GOMES e essa atribuição científica é suprimida da obra de DABUS MALUF.

Observe-se que, após a quase totalidade desse capítulo ser um texto "aproveitado" de MELLO e AMARAL, há a citação, em página 7, de obra do Professor ANTÔNIO JUNQUEIRA AZEVEDO. Tudo está entre aspas, fazendose pensar qual seria o motivo a mudança "metodológica". Do mesmo modo, pegue-se, por exemplo, as páginas 101 a 124. É um capítulo com muitas citações, porém todas entre aspas. 
É de se perguntar porque o mesmo "critério" não é utilizado nos termos apontados? Seriam indícios de intencionalidade no aproveitamento disfarçado do texto alheio? Há seguros indícios de má-fé, nessa hipótese.

Da mesma forma que a nossa avaliação anterior, entendemos improcedentes essas duas objeções pois: (a) não há plágio pois há a textual indicação do autor da obra citada e não houve dissimulação de pontos identificativos essenciais da obra utilizada e (b) foi praticado, pelo autor questionado, o regular exercício de direito de citação de passagens das obras preexistentes, na medida justificada para o fim a atingir, conforme a finalidade analítica-científica da monografia examinada, com expressa indicação do nome dos seus autores e a origem das obra citada, consignada de forma completa.

Em complemento, cabe observar quanto à primeira objeção: (a) quanto à afirmação de Clóvis Bebiláqua colocada em dúvida pelo requerentes do recurso, há na monografia indicação completa da fonte e - até - da respectiva página em que se encontra inserida ${ }^{52}$ e (b) a demonstração, na monografia, do efetivo acesso pelo autor questionado aos livros citados encontra-se patente em razão da indicação do nome e fontes completas (nome completo do autor, editora, local e ano da publicação e página respectiva), informações que não constam, dessa maneira completa, da obra citada de Marco Bernardes de Melo.

Quanto à segunda objeção, a menção ao jurista Francisco Amaral relativamente a trechos de duas páginas (p. 500 e 501) citadas de sua obra - é inserida, por quatro vezes $-p .5,6$ e 7 - no próprio texto citado, todas acompanhadas das respectivas notas de rodapé indicativas da fonte completa (e todas com a indicação da página da qual foi extraída a transcrição)..$^{53}$

Finalmente quanto à ilação de que haveria, por parte do autor questionado suposta "mudança metodológica" como "indício de intencionalidade no aproveitamento disfarçado de texto alheio" (sic) e "seguros indícios de má-fé" entendo ser desprovida de qualquer razoabilidade e, muito menos de base legal: trata-se, tal alegação, na verdade, de tentativa de despropositada ingerência estilística em obra alheia (a monografia questionada) em censura que representa nítida violação ao princípio constitucional de liberdade de expressão da atividade intelectual e científica, conforme já abordamos inicialmente no presente. ${ }^{54}$

52 "Clóvis Beviláqua. Teoria geral do direito civil. 2 ed; Rio de Janeiro : Franciso Alves, 1929, p.327.

53 Notas de rodapé 7 e $8(p .5) 9(p .6)$ e, ainda, no curso da mesma transcrição, há uma quarta nota de rodapé (n. 10, p. 7 indicativa da mesma passagem, todas extraídas de duas páginas - pp.500 e 501) da obra "Direito civil: introdução 2 ed. Aum. e atual. Rio de Janeiro : Renovar, 1998".

54 Itens 1.1. e 1.2. do presente (pp. 3 a 6) : Inciso IX do art. $5^{\circ}$ da Constituição Federal : “é livre a expressão da atividade intelectual, artística, científica e de comunicação, independentemente de censura ou licença". 


\subsubsection{Pesquisa referente a precedentes históricos}

Em relação a essa matéria de pesquisa, ressalve-se que não houve objeções no tocante à parte que tratou do "Direito Romano" (p. 10 a 14 - Capítulo 4) e também a que abordou o "Antigo Direito Luso-Brasileiro" (p. 26 a 29) mas no atinente ao "Direito Medieval" (p. 19 a 22 - Capítulo 5) e ao "Direito Costumeiro Francês" (p. 23 a 25 - capitulo 6). Portanto, das 16 páginas relativas à pesquisa histórica, a maior parte - 9 páginas - não foi objeto de crítica.

Nesse passo, vejamos essas objeções.

\subsubsection{Capítulo 5 - direito medieval}

Esta objeção não consta da peça inaugural do recurso mas é adicionada - desacompanhada de quadro comparativo-analítico - na manifestação de 20.03.2009 do Professor José Rogério Cruz e Tucci. Consigna, de forma genérica, que "todo o capítulo - praticamente sem tirar nem aduzir palavra alguma - é extraido de obra de terceiro, inclusive - o que é mais grave - com as mesmas referências citadas e notas de rodapé pelo autor do texto original' (destaque próprio).

Como não há a avaliação específica deste item na referida manifestação - mas apenas uma ilação de natureza geral, que engloba este e outros dois capítulos que examinaremos posteriormente no presente - torna-se dificultoso o respectivo exame do capítulo criticado.

De qualquer forma, a exemplo das objeções que já examinamos, entendemos improcedente também essa objeção pois: (a) não há plágio pois há a textual indicação do autor da obra citada e não houve dissimulação de pontos identificativos essenciais da obra utilizada e (b) foi praticado, pelo autor questionado, o regular exercício de direito de citação de passagens da obra preexistente, na medida justificada para o fim a atingir, conforme a finalidade analítica-científica da monografia examinada, com expressa indicação do nome do seu autor e a origem da obra citada, consignada de forma completa.

Em complemento, cabe destacar que a objeção não se sustenta também pois:

na p. 19 - Por se tratar de dois livros raros, dos séculos XVI e XVII, o autor questionado citou apud Antonio Masi, como se depreende dos "rodapés 1 e 2";

- $\quad$ na p. 20 - Também por se tratar de duas raras (Bartolo e Baldo), o autor questionado citou apud Antonio Masi, tendo os textos antigos em latim sido traduzidos pelo Prof. Inagcio M. Poveda Velasco, como indicado no "rodapé 3". 
nas p. 21 e 22 - Além da citação correta de Serpa Lopes (rodapé 4), o Professor Dabus Maluf também se valeu de outras pesquisas, como se nota pelos "rodapés ns. 5, 6, 7, 8 e 9", portanto não se valeu e nem se apropriou da pesquisa de SERPA LOPES, chegando, na verdade, além desta, uma vez que citou na sua monografia mais 5 autores (vide rodapés $n s$. $5,6,7,8$ e 9) de relevância inquestionável.

\subsubsection{Capítulo 6- direito costumeiro francês}

Esta objeção consta do recurso nos seguintes termos:

"Sobre essa questão de má-fé, o capítulo “6. Direito Costumeiro Francês" do candidato trouxe elementos intrigantes. Observe-se as páginas 23 a 25.

"Segundo Martinho Garcez e o Georges Lutzesco 2, no século XVI, Bertrand D'Argentré e Charles Dumoulin estabelecem nítida e claramente a teoria das nulidades de pleno direito e das nulidades dependentes de rescisão, doutrinando o primeiro que as nulidades de pleno direito não prescrevem nem podem ser confirmadas ou ratificadas; in totum nula, nec confirmari possit e que os contratos feridos pelas segundas são $a b$ initio valide post invalidi $=$ didati subjecti.

No século XVII, Louis Legrand faz a distinção entre contratos nulos de direito, de uma parte, e, de outra parte, contratos que subsistem desde o seu começo e podem ser rescindidos.

Ainda no século XVII, no Coutume D'Avvergne, utilizavamse as expressões nulo e sem nenhum efeito e nulo de pleno direito em lugar de nulidade absoluta ou radical.

Na segunda metade desse mesmo século XVII apareceu a obra de Domat, que exerceu grande influência sobre os redatores do Código Civil francês. Domat, com sua vasta intuição do direito, estabeleceu a distinção entre os contratos nulos na origem e os contratos sujeitos a resolução.

No século XVIII, François Ignace Dunod de Charnage com muit clareza estabelece a diferença entre nulidade absoluta $\mathrm{e}$ radical e nulidade respectiva.

A nulidade absoluta é a que provém da proibição de uma lei, cujo motivo principal é o interesse público.4

Ainda no século XVIII, Pothier fixou algumas regras importantes em matéria de nulidades, traçando a diferença 
entre atos nulos de pleno direito e anuláveis, que nos parece terem sido seguidas e aceitas pelos autores do código, e foi ele o primeiro jurisconsulto que, alo lado dos atos nulos de pleno direito e anuláveis, estabeleceu, também, as nulidades absolutas e relativas, teoria seguida pelo nosso Regulamento 737 , de 1850.5 .

Pothier segue o direito romano quanto às nulidades dos contratos relativos aos bens, ou contratos pecuniários, e segue o direito canônico, que lhe inspirou as nulidades absolutas e relativas, quanto aos contratos de casamento.6

Em matéria de casamento, a opinião de Pothier é que há casos em que este é nulo de pleno direito e não existe, por exemplo, quando não há consentimento; o erro sobre pessoa, diz ele, é incompatível com o que é de essência do casamento 7; mas os impedimentos dirimentes do casamento não o anulam: um casamento contratado com desprezo de um impedimento dirimente é um casamento viciado e, segundo o vício for absoluto ou respectivo, todos os interessados, ou alguns somente podem atacá-lo, e pedir sua anulação. Até a sentença o casamento subsiste e produz todos os seus efeitos; a sentença somente pode produzir a conseqüência de ser o casamento considerado retroativamente inexistente.

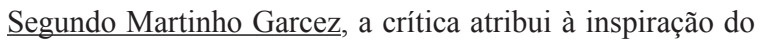
direito canônico essa doutrina em matéria de casamento, assim como atribui a doutrina em matéria de contrato pecuniário ao direito romano8".

Porém, a obra de MARTINHO GARCEZ (doc. 8)viii traz excertos muito semelhantes :

"No século XVI, d'Argentré 7 e Dumoulin 8 estabelecem nítida e claramente a theoria das nulidades de pleno direito e das nulidades dependentes de rescisão, doutrinando o primeiro que as nulidades de pleno direito não prescrevem nem podem ser confirmadas ou ratificadas: $<<$ in totum nula, nec confirmati possit e que os contratos feridos pelas segundas são - ab initio validi post invalidi - didati subjecti.

No século XVII, Legrand faz a distinção entre contractos nullos de direito, de uma parte, e, de outra parte, contratos que subsistem desde o seu começo e podem ser rescindidos 9.

\section{(...)}

....appareceu na segunda metade do século XVII, obra que exerceu grande influência sobre os redactores do codigo civil. Domat, com sua vasta intuição do direito, estabeleceu a distincção entre os contractos nulos na origem e os contractos sujeitos a resolução, nestas palavras : $<<$ Les conventions nulles sont celles quei manquent quelque 
caractère essentiel, on pas la nature d'une convention, comme si l'un des contractants etait dans quelque imbécilité d'esprit ou de corps, qui le rendit incapable de connaître à quoi il s'engage; si l'on autre vendu une shose publique, une shose sacrée ou autre, qui ne faut pas dans le commerce ou si la chose vendue était dejá propre à l'acheteur $>$.

10. No século XVIII, Dunod estabelece a differença entre nulidade absoluta e radical e nulidade respectiva, com nitidez que, dificilmente, pode ser excedida.

A nullidade absoluta é a que provém da prohibição de uma lei, cujo motivo principal é o interesse público, ouçamolo : $<<$ La nullité qui resulte de La prohibition em $\mathrm{CE}$ cãs absolue, pace que La loi resiste continuellement et que NE peut être ni confirme, ni autorisé, et qui NE produit aucun droit, aucune action, aucune exception. Cette nullité peut être objectée non seulement par La partie publique, mais encore par toutes sortes de personnes, sans qu'on puísse leur opposer qu'elles se prevalent du droit Du tiers; et Le juge peut et doit prendre égard d'office, quand personne NE La proposerait $>>13$.

Pothier, o grande sol que illuminou o berço do codigo Napoleão e que foi o guia dos autores desse codigo, principamente na parte de obrigações, fixou algumas regras importantes em matéria de nullidades, traçando a differença entre actos nullos de pleno direito e anulláveis, que nos parecem terem sido seguidas e acceitas pelos autores do codigo, e foi elle o primeiro jurisconsulto que, ao lado dos actos nullos de pleno direito e anulláveis, estabeleceu, também, as nullidades absolutas e relativas, theoria seguida pelo noss Regulamento 737, de 1850 (5).

Pothier segue o direito romano quanto às nullidades dos contractos relativos aos bens, ou contractos pecuniários, e segue o direito canônico, que lhe inspirou as nullidades absolutas e relativas, quanto aos contractos de casamento.

(...)

Em matéria de casamento, a opinião de Pothier é que há casos em que este é nullo de pleno direito e não existe, por exemplo, quando não há consentimento; o erro sobre a pessoa, diz elle, é incompativel com o que é de essência do casamento(17); mas os impedimentos dirimentes do casamento não o anullam: um casamento contractado com desprezo de um impedimento ririmente é um casamento viciado e, segundo o vício for absoluto ou respectivo, todos os interessados, ou alguns somente podem atacar o casamento, e pedir a sua anullação. Até a sentença o casamento subsiste e produz todos os seus effeitos; a 
sentença somente pode produzir a conseqüência de ser o casamento considerado retroactivamente nunter existido. [NÃO HÁ PARÁGRAFO] A crítica atribue à inspiração dodireitocanônico essa doutrina em matéria de casamento, assim como atribue a doutrina em matéria de contracto pecuniário ao direito romano".

Entre um trecho e outro, percebe-se que o candidato adéqua a ortografia do autor à época da obra. Contudo, algumas alterações no texto sugerem, realmente, a intencionalidade de querer passar como seu o texto original.

Anote-se que, entre um trecho e outro, autores recebem nome na obra do candidato: "Bertrand D'Argentré e Charles Dumoulin, Louis Legrand e François Ignace Dunod de Charnage" são, para a obra de GARCEZ, "d'Argentré(7) $e$ Dumolin(8), Legrand, E Dunod".

Alem disso, algumas alterações no texto também indicm a suposta intenção de apropriação do texto alheio. Na obra de DABUS MALUF, a sentença "Na segunda metade desse mesmo século XVII apareceu a obra de Domat, que exerceu grande inluência sobre os redatores do Código Civil francês" corresponde ao excerto de GARCEZ ao seguinte parágrafo: “....appareceu na segunda metade do século XVII obra que exerceu grande influência sobre os redatores do codigo civil.".

Na obra do candidato, o período "François Ignace Dunod de Charnage com muita clareza estabelece a diferença entre nulidade absoluta e radical e nulidade respectiva" corresponde a "No século XVIII, Dunod estabelece a differença entre nullidade absoluta e radial e nullidade respectiva, com nitidez que, difficilmente, pode ser excedida", na obra de GARCEZ.

Do mesmo modo "parece" corresponde a "parecem", ou seja, há a supressão do plural no verbo e "atacá-lo" corresponde a "atacar o casamento".

Esses "pontos nebulosos" dificultam a tese de que não houvesse a intenção de DABUS MALUF em se aproveitar da redação da obra alheia, apresentando como sua - porque ausente o uso de aspas que, em outras partes de sua "tese original", é utilizada.

Essa sugestão de intencionalidade parece evidente quanto às notas de rodapé de números 3 e 4 na página 24 da obra do candidato. Como se percebe nos destaques em azul, na obra de GARCEZ, parte de seu texto foi indicado, por DABUS MALUF, em forma de nota de rodapé. 
É possível entender que, nessa hipótese, ao suprimir que se tratava de citação de citação ( "apud"), ou seja, citação de um texto em que o Dr. DABUS MALUF não teve acesso ao original."(destaques próprios)

Embora extensa - em razão de transcrições literais extraídas de 3 páginas da monografia - aplica-se a estas críticas, da mesma forma que adotamos nas questões anteriores, o nosso entendimento pela improcedência das objeções pois : (a) não há plágio pois há a textual indicação dos autores das obras citadas e não houve dissimulação de pontos identificativos essenciais das obras utilizadas e (b) foi praticado, pelo autor questionado, o regular exercício de direito de citação de passagens de obras preexistentes, na medida justificada para o fim a atingir, conforme a finalidade analítico-científica da monografia examinada, com expressa indicação dos nomes do seus autores e a origem das obras citadas, consignada de forma completa.

Em complemento, cabe observar que a indicação, de forma completa, das fontes pesquisadas não consta da obra citada, de Martinho Garcez, mas sim da monografia ora examinada. ${ }^{55}$ Com efeito, Garcez cita apenas o nome "Dounod" - grafado incorretamente pois o certo é "Dunod" como consta da monografia em questão - e não a fonte de forma completa, como consta da obra de Dabus Maluf criticada, ${ }^{56}$ o que demonstra o louvável critério de refinamento da pesquisa originária devidamente citada e revista, como próprio de toda obra de cunho científico.

\subsubsection{Capítulo 10 - causa e objeto}

Os Capítulos 7 (A Inexistência no Antigo Direito LUSO-BRASILEIRO), 8 (Legislações que Consagram a Inexistência) e 9 (Características que Consagram a Inexistência), correspondentes às 11 páginas seguintes não foram objeto de crítica.

As objeções voltam no Capítulo 10 - Causa e Objeto, ${ }^{57}$ consubstanciadas em 3 páginas, nos seguintes termos:

55 Nesse sentido, por exemplo, anota de rodapé de $\mathrm{n}^{\circ} 3$ ( $p .24$ da monografia em questão) em que consta : "Jean Donat, Le Lois civiles dans leur ordre naturel. Paris. Nyon, 1777, 1.1., p. 29" acompanhada da "lição textual" do jurista citado. Na obra citada de Martinho Garcez, ao contrário, há apenas um resumo da lição de Donat e a indicação singela do nome desse jurista (sem o prenome), o que demonstra o efetivo acesso do Professor Dabus Maluf a essa obra.

56 Vide nota de rodapé de $n^{\circ} 4$ ( $p .24$ da monografia em questão) em que consta : "François Ignace Dunod de Charnage. Traité de prescription de l'alienation des biens d'Eglise et des diximes suivant les droits civile et canon, la jurisprudence du Royaume e les usages du comité de Bourgogne. 4. ed. Paris: Briasson, 1786, p. 47.

57 Como ja' registramos em nossa nota de rodapé de n. 48 ( $p .33$ do presente, em relação a esta objeção - $p .37$ a 39 da monografia em questão) há nos autos do processo administrativo manifestação de 23.07.2008 dos filhos do jurista Paulo Barbosa de Campos Filho, representados por sua advogada Angela M. Teixeira Leite Pacheco Di Francesco endossando a acusação ora examinada. 
"Nas páginas 37 a 39 da obra de DABUS MALUF, há o capítulo "10, Causa e Objeto", que reputamos ser ele integralmente extraído ipsis litterir, ipisis verbis da obra de PAULO BARBOSA CAMPOS FILHO (DOC.9) (ix), embora há a completa "abstração" do necessário uso de aspas.

Nesse caso, é possível afirmar que um capítulo inteiro da obra de DABUS MALUF não é de sua autoria intelectual. Observe-se:

(...)

Com esse excerto, crescem as evidências de que DABUS MALUF intencionalmente não escreveu com a honestidade científica necessária à "tese original" queo o qualificaria para a sua habilitação para o cargo, eis que, repita-se mais uma vez, há um capítulo inteiro sem a citação de aspas, com as pequenas alterações que, no quadro comparativo acima, são evidentes.

A questão, aqui, não é outra senão essa: a falta de honestidade científica altera a veracidade da pesquisa.

Não importa que a flta de aspas (relembre-se: sempre utilizadas em outros tantos capítulos da "tese original" de DABUS MALUF) aproveite indevidamente da obra alheia - in causu, a do Professor Paulo Barbosa de Campos Filho. Mais que esse importante dado, é de se anotar que HÁ A SUPRESSÃO DA ATRIBUIÇÃO DO PENSAMENTO ORIGINAL DAS NOTAS DE RODAPÉ DE No 77, 78, 79, 80, 81, 82 E 86, ou seja, a contribuição de André Lalande, Japiot, Beudant e Giuseppe Stolfi para as conclusões científicas em questão.

De outro modo, DABUS MALUF suprime o pensamento de formação das conclusões de pesquisa realizada pelo Professor PAULO BARBOSA DE CAMPOS FILHO, maculando a precisão científica que é esperada em uma obra desse escol, que é uma tese de concurso para preenchimento de vaga como Professor Titular". (destaques próprios)

Da mesma forma que consignamos em relação às hipóteses anteriores, entendemos improcedente a objeção pois: (a) não há plágio pois há a textual indicação do autor da obra citada e não houve dissimulação de pontos identificativos essenciais da obra utilizada e (b) foi praticado, pelo autor questionado, o regular exercício de direito de citação de passagens da obra preexistente, na medida justificada para o fim a atingir, conforme a finalidade analítica-científica da monografia examinada, com expressa indicação do nome do seu autor e a origem da obra citada, consignada de forma completa. 
Em complemento, observe-se que a transcrição, já na sua primeira linha ( $p$. 37) indica o nome completo do jurista ("Segundo a lição de Paulo Barbosa de Campos Filho") destacando, assim, tratar-se de "lição" do autor citado, reeditando, no próprio texto, a mesma indicação (p. 38): "Responde Paulo Barbosa de Campos Filho...", bem como de sua obra ${ }^{58}$ e respectiva página citada ( $\left.p .50\right)$ em duas notas de rodapé ( $n s 1, p .38$ $e 2, p .39)$. Não se apropria, assim, o autor questionado, de texto de outrem como se próprio fosse, mas, pelo contrário, encontra- se claro que se trata de texto citado, extraído de obra preexistente, em passagens relevantes trazidas em sua integridade e respeitosamente - sem fragmentação do pensamento do jurista Paulo Barbosa de Campos Filho - como opção de natureza informativo-científica inserida na monografia em questão.

3.2.5. Capítulo 11 - falta de objeto e item 14.5 do capítulo 14 - estudo de Catherine Guelfucci-Thibierge

Das 5 páginas integrantes do Capítulo 11 ( $p .40$ a 44) há objeção em relação a 3 ( $p .40$ a 42) . No mesmo item ( $6^{a}$ objeção consignada no recurso) se insere a crítica a uma das cinco partes, intitulada "Estudo de Catherine Guelfucci-Thibierge" ( $p .69$ a 73 - 5 páginas, portanto) do capítulo 14 ("Doutrina Francesa"), consubstanciado este em 26 páginas (p. 51 a 76). Vejamos, então essa duas objeções:

(a) - primeira objeção: páginas 40 a 42

“Os 9 (nove) primeiros parágrafos do Capítulo 11 (páginas 40 a 42) da obra de DABUS MALUF trazem, outra modalidade de violação de originalidade e honestidade acadêmicas: trata-se de mera tradução servil de texto alienígena. Anotese: (...transcrição dos textos referidos...)

A comparação entre um texto e outro evidencia que DABUS MALUF apenas efetuou a tradução do texto em língua espanhola, fazendo referência ao mesmo apenas no segundo parágrafo da página 41 , na nora de rodapé $n .2$.

Há, nesse texto, elementos que sugerem um intenção do candidato em se apropriar do texto alheio, tratando-se, a exemplo do que ocorreu com a obra de GARCEZ de fraudar a originalidade científica ao referenciar em nota de rodapé a pesquisa que, em verdade, foi realizada por sua "fonte". Atente-se pra as notas de rodapé de $\mathrm{n}^{\circ} 2$ a 4 , na página 42:

"2 Charles Demolombe, Cours de Code Napoleón: traitè dês contrats ou dês obligations conventionnelles em générale.

58 "Paulo Barbosa de Campos Filho. O problema da causa no Código Civil Brasileiro. São Paulo. Max Limonad, (sem data), p. 50" 
Paris: Hachette, 1877.t.24, n. 299-321; F. Laurent, Principes de droit civil français. 3. ed. Paris: Libr. ${ }^{a}$ Marescq Ainé, 1878.t. 16, n. 76; Theóphile Huc, Commentaire thèorique et pratique du Code Civil. Paris: Pichon, 1892-1903. t. 7, n. 67.

3 Charles Demolombe, cours de Code Napoléon ...cit. T. 24, n. 316; F. Laurent, Principes de droit civil... cit. T. 16. n. 80; Theóphile Huc, Commentaire thèorique cit. t. 7, n. 90.

4.Julien Bonnecase, Supplèment au Traité de BaudrtLacantinerie. Paria, 1924-1935.t.3, p. 140”

Ao escrever tais notas de rodapé, ocandidato quis transprecer a falsa idéia de que teria consultado as fontes Demolombe e Bonnecase. Porém, como se tira das notas de rodapé de $\mathrm{n}^{\circ}$ 41 a 43 de LUTEZCO, tal pesquisa não foi realizada por DABUS MALUF, que inclusive suprime o pensamento de outros autores, apontados na "fonte" original.

“41 DEMOLOMBE, t. XXIV, núms. 299 y 231; LAURENT, t. XVI, num.76; HUC, t. VII, num.67, BAUDRY

LACANTINERIE y BARDE, Oblig., t. I, pág. 296; AUBRY y RAU, t. IV, pág. 534.

42 DEMOLOMBE, t. XXIV, n. 316; LAURENT, t. XVI, n.80; HUC, t. VII, pág.98; BAUDRY LACANTINERIE y BARDE, t. I, pág. 329; AUBRY y RAU, t. IV, pág. 534.

43 BONNECASE, Suppl., t. III, pág. 140 y Précis de Droit Civil, t II, pág. 292; JOSSERAND, T. II, PÁGS. 58 Y 60.”

Entendemos que tal ponto frauda a honestidade científica que se esperava, imprimindo rigorosa nulidade da "tese original" do candidato."

(b) - segunda objeção : páginas 69 a 73

"Mas esse tipo de modus operandi não se encerra no texto em espanhol, pois há traduções de textos em língua francesa que obedecem a mesma conduta.

Observe-se em outro quadro comparativo, bem ilustrador: (...transcrição dos textos referidos...).

Como se vê, 5 (cinco) páginas (69 a 73) são, pois, tradução livre (e não citação) de obra estrangeira, sendo que DABUS MALUF faz referência à obra nas notas de rodapé de $\mathrm{n}^{\mathrm{0}} 25$ e 27.

Como em LUTEZCO, o candidato suprime as fontes originais da obra estrangeira, pois é possível identificar, na obra de CATHERINE, os pensamentos de $\mathbf{M}$. HEBRAUD, COUTURIER, DELOMBE III, ROBIER, 
BUFNOIR, AUBRY et RAU, BEUDANT, JAPIOT, GAUDEMET, LA PRADELLE, GHESTIN, FLOUR et AUBERT, LARROUMET, CAPITANT, FRENISY, BAUDRY-LACANTINERIE, PLANIOL et RIPERT, HUGUENEY,

DROGOUL, BERTRAND, CHEVALLIER, CARBONNIER, LUTEZCO, CAPITAIN, COLIN et CAPITANT par JULIOT de La MORANDIERE II, RIPERT et BOULANGER II, MAZEAUD et CHABAS II, LARROUMET, PONSAR et BLONDEL, BURRY, ROUBIER, BANDRAC, GAMMAL e DUPEYRON, nas notas de rodapé de $\mathrm{n}^{\circ} 3$ a 47.

Assim, CATHERINE em verdade tira suas conclusões de outros tantos autores e o candidato, ao não apontar tais fontes, está a retirar os créditos do pensamento original de sua "fonte" francesa, retirando a credibilidade em sua própria tese, porque imprecisa e incompleta."

Da mesma forma que as anteriores, em relação a ambas objeções, entendemos improcedentes pois: (a) não há plágio pois há a textual indicação dos autores das obras citadas e não houve dissimulação de pontos identificativos essenciais da obra utilizada e (b) foi praticado, pelo autor questionado, o regular exercício de direito de citação de passagens das obras preexistentes, na medida justificada para o fim a atingir, conforme a finalidade analítico-científica da monografia examinada, com expressa indicação do nome dos seus autores e a origem das obras citadas, consignada de forma completa.

Em complemento, destacamos, em relação à primeira objeção que o autor questionado não foge à fidelidade da citação do texto traduzido, como demonstra a própria peça acusatória, restando, também, comprovado o inegável acesso às obras originais (aliás clássicas no direito civil) nesse caso - até - o refinamento da indicação da pesquisa realizada pelo Professor Dabus Maluf pois - a própria transcrição trazida nesta objeção comprova - é mais completa do que a da fonte citada (nesta os nomes dos juristas não estão completos e não há a indicação do título da obra).

Quanto à segunda objeção, resta patente a indicação, pelo autor questionado, de que trata-se de estudo - que este optou por trazê-lo sem fragmentação mas sim, de forma mais completa - da jurista Catherine Guelfucci-Thibierge, com grande destaque, uma vez que intitula essa parte do capítulo 14 (item 14.5) de "Estudo de Catherine Guelfucci Thibierge". Além disso, há no curso da citação 5 notas de rodapé indicativas da fonte respectiva (pp. 71, 72, 73, 74 e 76). Acrescente-se que a contribuição do autor questionado não se limita à tradução do texto citado mas, também, consistiu na elaboração - em poucas páginas da monografia - de síntese do pensamento da jurista citada, pensamento este 
desenvolvido em texto substancialmente mais extenso : mais de 30 páginas (pp. 205 a 236 da obra citada), devidamente indicadas nas notas de rodapé pelo Professor Dabus Maluf.

\subsubsection{Item 24.3. do Capítulo 24 - ausência total de consentimento}

O recurso em tela, após passar a íntegra de nove capítulos (do 15 ao 23) da monografia "in albis" vai apontar sua última objeção no item 24.3. do Capítulo 24 : das 11 páginas que compõem este capítulo (pp. 139 a 149) 2 são objeto de crítica (pp. 147 e 148). Nesse âmbito, consigna o recurso o seguinte:

"Finalmente, anote-se que nas páginas 147 e 148 da obra de DABUS MALUF, há excerto muito coincidente com obra de - pasmem! - um dos professores que compuseram a banca examinadora :

(...transcrição das duas obras referidas, sendo o professor referido ÁLVARO VILLAÇA AZEVEDO...)

Dado que intelligenti pauca, deixa-se de comentar a obviedade em constatar-se a paráfrase de um texto em outro, em absolutamente nada inovando o que já fora dito, anotando-se que até as notas de rodapé são rigorosamente as mesmas em ambas as obras.

Da mesma forma dos exemplos anteriores, entendemos improcedente a objeção pois: (a) não há plágio pois há a textual indicação do autor da obra citada e não houve dissimulação de pontos identificativos essenciais da obra utilizada e (b) foi praticado, pelo autor questionado, o regular exercício de direito de citação de passagens da obra preexistente, na medida justificada para o fim a atingir, conforme a finalidade analítico-científica da monografia examinada, com expressa indicação do nome do seu autor e a origem da obra citada, consignada de forma completa.

Com efeito, o Professor Álvaro Villaça Azevedo e sua obra, edição, cidade, página encontram-se regularmente citados na nota de rodapé de n. 15 da p. 147 da monografia criticada. ${ }^{59}$ Além disso, o jurista é citado no curso do próprio texto da obra em exame por duas vezes: nas p. 146 e 147. Encontra-se claro, portanto, que as transcrições ou referências foram extraídas da sua obra, devidamente identificada.

Quanto à referência jurisprudencial, a fonte é, também, corretamente indicada em duas notas de rodapé ( $n^{\circ} s 16$ e 17) na p. 148 da monografia em exame. ${ }^{6061}$

\footnotetext{
59 "Álvaro Villaça Azevedo, União entre pessoas do mesmo sexo. Revista da Faculdade de Direito da Universidade de São Paulo, v. 94, p. 14-15, 1999.

${ }^{60}$ Nota 16: "Revista dos Tribunais, São Paulo, v. 572, p. 189. Apelação Cível no 56.899" e Nota 17: "Revista dos Tribunais, São Paulo, v. 615, p. 47. Apelação Cível n. 71.597-1”.
} 


\subsubsection{As Objeções Apresentadas pelo Professor José Rogério Cruz e Tucci}

Como já nos referimos no item 3.2.3.1. do presente, existem objeções à monografia em exame que não constam da peça inaugural do recurso mas são adicionadas - desacompanhadas de quadro comparativo-analítico - pela manifestação de 20.03.2009 do Professor José Rogério Cruz e Tucci. Critica, de forma genérica, o estilo de citação do autor em questão - em especial a dispensa de aspas em relação a alguns textos citados (o que - as aspas - como já examinamos "ex abundantia” no presente, consistem em uma forma de utilização de obras preexistentes mas não a única). Acrescenta, também, de forma genérica, que em relação a três capítulos "praticamente sem tirar nem aduzir palavra alguma - é extraído de obra de terceiro, inclusive - o que é mais grave - com as mesmas referências citadas e notas de rodapé pelo autor do texto original" (destaque próprio).

Como não há a avaliação específica deste item na referida manifestação - mas apenas uma ilação de natureza geral, que engloba os capítulos constantes das páginas 19 a 22 - direito medieval; das páginas 175 a 179 - atos inexistentes no processo e das páginas 180 a 187 - sentença inexistente - torna-se dificultoso o respectivo exame do capítulo criticado.

De qualquer forma, relevante destacar a impropriedade dessas objeções - consignadas no plano genérico - tendo em vista as seguintes especificidades que contradizem frontalmente tais ilações:

(a) em relação às citações:

- $\quad$ p. 14 - No "rodapé 1" foi feita na monografia a citação de Antonio Masi, tendo sido traduzido livremente o texto italiano publicado na "Enciclopedia Del Diritto";

- $\quad$ p. 77 a 81 - Além de Eduardo Espinola foram citados na monografia Georges Lutezco (P. 78, rodapé 2 e p. 80 rodapé 5); Henri de Page, Claude Renard e M. E. Vieujean (p. 81, rodapés 8 , 9 e 10).

- $\quad$ p. 121 a 124 - Além de Eduardo Lobo Botelho Gualazzi, foram citados à p. 122, Caio Mário de Silva Pereira e Silvio Rodrigues (pp. 122, rodapés 2 e 3).

- $\quad$ p. 156 a 158 - O capítulo onde estão incluídas as páginas 156 a 158 chama-se "Casamento inexistente e casamento putativo", que começa na p. 154, neste capítulo estão citados Yussef Said Cahali (p. 154 e 155, rodapés 1, 2, 3 e 4), J. M. Carvalho Santos (P. 155, rodapé 5 com um julgado) e finalmente Mario Moacir Porto (p. 155 rodapé 6$)$, portanto 
nestes capítulos foram citados três autores, não estando amparada a monografia em questão, neste aspecto, apenas na lição de Mario Moacir Porto, como consignado na objeção em referência.

(b) em relação aos 3 capítulos criticados:

o primeiro capítulo referido ( "direito medieval" - p. 19 a 22) encontra-se examinado nas p. 44 a 46 do presente (concluindo-se pela improcedência da objeção)

no segundo capítulo referido ("atos inexistentes no processo" - pp. 175 a 179) : foram citados Jose Frederico Marques (p. 175, rodapé 1), Humberto Theodoro Júnior ( $p$. 175, rodapé 2), Teresa Arruda Alvim Pinto (p. 177, rodapé 3, p. 178, rodapé 8 e 10 p. 179 rodapé 11), Eduardo Couture (p. 177 rodapé 4 e 5), Jorge $\mathrm{P}$. Camusso (p. 177 rodapé 6), Alberto Luis Maurino (p. 178, rodapé 7 e 9), portanto não somente da pesquisa de Teresa Arruda Alvim Pinto, tendo em vista inclusive, que foi consignada na monografia a citação de José Frederico Marques (rodapé 1 da p. 175) que não foi citado por Teresa Arruda Alvim Pinto, assim a pesquisa do Professor Dabus Maluf é injustamente criticada, pois, na verdade, chegou, inclusive, a acrescentar novos elementos à pesquisa realizada por Teresa Arruda Alvim Pinto.

- no terceiro e último capítulo criticado ("Sentenças Inexistentes" p. 180 a 187) : foram citados, Candido Rangel Dinamarco ( $p$. 180, rodapé 1 e 2), Teresa Arruda Alvim Pinto (p. 180 rodapé 3 , p. 181 rodapé 4 e 5, p. 183 rodapé 7 e 9, p. 184 rodapé 11 e 13, p. 185, rodapé 17), Tullio Ascarelli apud Candido Rangel Dinamarco (p. 181, rodapé 5), Luiz A. Rodrigues (p.184, rodapé 10), julgado (p. 184, rodapé 12) Ada Pellegrini Grinover (p. 185, rodapé 14). Coqueijo Costa ( $p .185$, rodapé), julgado ( $p .185$, rodapé 16), além desses autores citados por Teresa Arruda Alvim Pinto, o Professor Dabus Maluf citou fruto de sua pesquisa, J. J. Calmon de Passos (p. 185 e 187, rodapés 18 e 19), portanto, e mais uma vez, chegando além da pesquisa de Teresa Arruda Alvim Pinto.

De qualquer forma, a exemplo das objeções que já examinamos, entendemos improcedentes essas duas objeções pois: (a) não há plágio pois há a textual indicação do autor da obra citada e não houve dissimulação de pontos identificativos essenciais da obra 
utilizada e (b) foi praticado, pelo autor questionado, o regular exercício de direito de citação de passagens das obras preexistentes, na medida justificada para o fim a atingir, conforme a finalidade analítico-científica da monografia examinada, com expressa indicação do nome dos seus autores e a origem das obras citadas, consignada de forma completa.

4. Conclusões: respostas aos quesitos formulados pelos consulentes

Em face de todo o exposto até aqui e a título de conclusão, passo à resposta dos quesitos formulados pelos Consulentes:

1) Qual o conceito de plágio? Há plágio na tese do Professor Carlos Alberto Dabus Maluf?

Resposta: Conceituamos o plágio no item 1.3 do presente (p. 12 a 19). Entendemos que não há plágio na tese do Professor Carlos Alberto Dabus Maluf conforme examinamos: (a) sob o aspecto genérico: capítulo 2 do presente (p. 19 a 31) e (b) sob aspecto específico (em relação a cada objeção levantada em relação à monografia em questão) no capítulo 3 do presente (p. 31 a 65$)$.

2) APortaria da Faculdade de Direito determina a apuração de eventuais irregularidades na tese. No âmbito do direito autoral, qual o conceito de irregularidade? Há irregularidade na tese?

Resposta: Examinamos a questão atinente à alegada existência de irregularidade na monografia : (a) no plano genérico teórico, no âmbito constitucional (item 1.1. - p. 3 a 6) e infraconstitucional com ênfase no campo do direito autoral (item 1.2 e seus subitens 1.2.1, 1.2.2., 1.2.2.1. e 1.2.2.2. - p. 6 a 12), e (b) no plano específico do caso concreto na órbita do direito positivo vigente (item 2.2.2., p. 30 e capitulo 3, p. 32 e 33) e a sua aplicação em relação a cada objeção levantada (itens 3.1. a 3.7 - p. 31 a 65). No contexto da orientação legal atinente a direito autoral que expusemos nos referidos itens do presente, entendemos não haver irregularidades na tese "A inexistência na teoria das nulidades" de autoria do Professor Carlos Alberto Dabus Maluf.

3) Quando há a alegação de que houve cópia de um determinado trabalho, como devemos enquadrar juridicamente tal alegação? Quais os elementos que caracterizam a cópia? Há permissão legal para a cópia? Se há, em que termos?

Resposta: Tratamos do regime jurídico do direito de citação, de forma ampla, no item 1.2., p. 6 a 12 do presente, o que esclarece as questões consignadas neste quesito. 
4) A tese do Professor Carlos Alberto Dabus Maluf copiou alguma das obras dos autores citados?

Resposta: As transcrições de passagens de obras preexistentes foram efetivamente incorporadas à monografia do Professor Carlos Alberto Dabus Maluf, de forma regular, com a devida identificação de origem e indicação de autoria, como próprio de obras intelectuais de natureza científica (acadêmica).

5) Quais os limites para a transcrição de pensamentos de outros autores?

Resposta: Tratamos deste tema específico no item 1.2.2.2. do presente (p. 10 a 12).

6) Qual a correta interpretação do art. 46, III, da Lei de Direitos Autorais? A tese do Professor Carlos Alberto Dabus Maluf ofendeu direitos autorais?

Resposta: O nosso entendimento sobre a adequada hermenêutica do inciso III do art. 46 da Lei n. 9.610/98 encontra-se consignado, no plano teórico, no item 1.2.2.2. do presente (p. 10 a 12) e no plano concreto do caso em exame nos capítulos 2 e 3 (p. 19 a 65) levando à conclusão segura de que não houve ofensa de direitos autorais em relação às obras preexistentes citadas na tese do Professor Carlos Alberto Dabus Maluf.

7) Como classificar as normas da ABNT dentro do Direito Autoral? Qual a relação das normas da ABNT com a Lei de Direitos Autorais? O desrespeito às normas da ABNT caracteriza infração à Lei de Direitos Autorais?

Resposta: O regime jurídico do direito autoral, especialmente no que tange ao direito positivo constitucional e infraconstitucional (Lei n. 9.610/98), não se subordina às normas de cunho técnico-formal da ABNT-Associação Brasileira de Normas Técnicas e, conseqüentemente o seu eventual desatendimento não representa, necessariamente, que deva resultar em violação de direito autoral de qualquer natureza.

8) Na apresentação de um trabalho acadêmico quais s normas legais de direito autoral que o candidato deve respeitar? Na apresentação de uma tese para titularidade há requisitos diferentes? Há uma técnica de redação que obrigatoriamente deve ser obedecida pelo candidato?

Resposta: Tratamos dessa questão já no início do presente (item 1.1. e 1.2. - p. 3 a 6), entendendo que, uma vez que não se incorra em violações de direito autoral, é inconstitucional a subordinação do exercício da liberdade de expressão da atividade 
intelectual, especialmente no âmbito de obras de natureza científica, a padrões técnicos e formais preestabelecidos.

9) A ausência de aspas numa citação com a indicação da fonte caracteriza ilícito à Lei de Direitos Autorais? O que caracteriza tal fato?

Resposta: A ausência de aspas numa citação de obra de terceiros não implica, necessariamente, em infração aos direitos autorais correspondentes uma vez que se encontre indicado, pelo autor da obra nova, na citação, o uso, nessa sua obra nova, da obra preexistente. Não há na legislação aplicável à matéria qualquer disposição sobre a exigência de utilização de aspas nesses casos (vide, a respeito, ainda, o item 1.2., p. 3 a 10 e os itens 2.1.2., p. 22 e 23 do presente).

10) A separação do texto em parágrafos que não constam do original sem aspas caracteriza ilícito à Lei de Direitos Autorais? O que caracteriza tal fato?

Resposta: A separação ou reorganização do texto citado com ou sem aspas em parágrafos, diferentemente da forma consignada no texto originário, não resulta em ofensa ao direito autoral do autor da obra utilizada uma vez que haja fidelidade ao texto transcrito, ou que não haja a dissimulação da sua forma ou conteúdo em tentativa de descaracterizar a sua autoria originária, com indicação clara e completa da fonte respectiva (nome do autor, dados sobre a obra e página correspondente). A violação a direito autoral somente se caracterizará nas hipóteses que examinamos nos itens 1.2.2.2. (p. 10 a 12) e 1.3. (p. 12 a 19) do presente.

11) A tese do Professor Carlos Alberto Dabus Maluf apresentou a intenção de apropriação do texto alheio?

Resposta: Não encontramos, em nenhuma das objeções examinadas (todas tratadas no capítulo 3 do presente - p. 31 a 65), qualquer intenção de apropriação, pelo Professor Carlos Alberto Dabus Maluf, de texto alheio. Ao contrário, todas as passagens de obra preexistentes citadas pelo jurista em questão encontram-se identificadas e acompanhadas dos devidos créditos (vide p. 31 a 65, ainda, do presente).

12) Qual a importância da boa-fé para o direito autoral? Na tese do Professor Carlos Alberto Dabus Maluf há como identificar a presença ou ausência de boa-fé?

Resposta: À boa-fé objetiva, por se constituir um princípio geral, aplica-se, naturalmente, ao direito de autor. Na tese do Professor Carlos Alberto Dabus Maluf não identificamos 
hipóteses de presença de má-fé, muito ao contrário, em razão do cuidado que constatamos pelo Professor em indicar claramente o nome e obra dos autores citados a partir de quase 200 obras pesquisadas. (vide p. 31 a 65 ainda).

13) Quando há tradução de uma obra, como esta deve ser feita nos termos da Lei de Direito Autorais? A tese do Professor Carlos Alberto Dabus Maluf cometeu infração quando traduziu a obra de Catherine Guelfucci-Thibierge e Georges Lutzesco?

Resposta: A tradução de uma obra deve seguir, da forma mais fidedigna possível, o sentido da obra originária traduzida, a não ser que se trate de adaptação consentida ou paráfrase (que é livre nos termos do art. 47 da Lei 9.610/98). Conforme se depreende do item 3.2.5 do presente (pp. 54 a 58), em que examinamos, especificamente, esta questão, entendemos que não houve infração de direitos autorais na citação da obra de Catherine GuelfucciThibierge e Georges Lutzco.

14) Quando há citação de um julgado de um Tribunal, citado também em outra obra, como deve ser feita a indicação? E se não se conhecer que outra obra, anterior, citou o mesmo julgado, qual o enquadramento desta situação?

Resposta: Examinamos esta questão quanto à especificidade do caso em exame nas p. 59 e 60 do presente, consignando o nosso entendimento pela efetiva regularidade da citação, pelo Professo Dabus Maluf, da fonte jurisprudencial em questão.

15) Na tese do Professor Carlos Alberto Dabus Maluf houve citação da obra de Paulo Barbosa de Campos Filho? Houve alguma infração à lei ou irregularidade no que tange à obra de Paulo Barbosa de Campos Filho?

Resposta: Examinamos esta questão específica nas p. 53 a 55 do presente e concluímos que não houve qualquer irregularidade nessa citação.

16) Há na tese do Professor Carlos Alberto Dabus Maluf ausência de menção remissiva ou bibliográfica aos autores citados no recurso?

Resposta: Não. As menções remissivas ou bibliográficas foram devidamente realizadas conforme examinamos no capítulo 3 do presente, p. 31 a 65.

17) No âmbito do direito autoral, pode ser imputada ausência de originalidade e 


\section{honestidade científica à tese do Professor Carlos Alberto Dabus Maluf?}

Resposta: Absolutamente. É patente e indiscutível, como examinado, ao longo deste parecer, a honestidade científica do Professor Carlos Alberto Dabus Maluf bem como a originalidade e ineditismo de sua monografia, em questão (vide, nesse sentido, entre outras, as p. 28 a 30 do presente), próprios ao elevado grau de sua qualificação acadêmica e profissional (conforme p. 24 a 27 do presente).

\section{Encerramento: um precedente relevante}

A título de desfecho do presente, entendo relevante trazer à consideração precedente emblemático, ocorrido também em concurso acadêmico na Faculdade de Direito da Universidade de São Paulo, da mesma natureza do que acabamos de examinar, relatado por José Afonso da Silva: ${ }^{61}$

(a) os fatos:

Outro concurso tumultuado foi o que Ada Pellegrini Grinover disputou para o cargo de Professor Titular de Direito Processual Penal, com a tese Liberdades Públicas e Processo Penal : As Interceptações Telefônicas. Seu concorrente, Rogério Lauria Tucci, esquadrinhou-lhe a monografia frase por frase, palavra por palavra, para provar a existência de plágio e o denunciou à Congregação. Para tanto, marcou textos, e mais textos, em confronto com textos de autores italianos, especialmente, para demonstrar o decalque. Formado o processo para apreciação da imputação, foi ele submetido à Congregação.

(b) o processo e a primeira decisão (da Congregação):

Iniciada a discussão, pedi vista para examinar a matéria com mais profundidade, já que se tratava de uma acusação muito séria sobre uma professora que eu conhecia desde os bancos escolares, por ser minha colega de turma, e sabia de sua honestidade intelectual. Examinei com cuidado sua tese como a tese do concorrente.. Encontrei defeitos técnicos em ambas, mas não vislumbrei plágio, até porque os autores tidos como plagiados estavam referenciados na monografia, Meu parecer, lido na sessão da Congregação, concluía pela inexistência de plágio e, pois, pela aceitação do pedido de inscrição. Fui apoiado expressamente por Fábio Konder Comparato, Dalmo de Abreu Dallari e outros,

${ }_{61}$ A Faculdade e meu Itinerário Constitucional, Malheiros Editores, São Paulo, 2007, p. 605. 
tendo a Congregação aprovado meu parecer com a recusa da imputação.

(c) o recurso e a confirmação do veredicto pelo Conselho Universitário:

Lauria Tucci não se conformou e recorreu ao Conselho Universitário, mas aí também não teve êxito. Além disso, a acusada juntou correspondência daqueles autores que, segundo a imputação, tiveram suas obras plagiadas, os quais não encontraram fundamento na acusação. Mas o problema não estava definitivamente julgado, porque, em tais casos, cabe à banca examinadora, em reunião preliminar, decidir da existência ou não de plágio. A reunião concluiu pela inexistência de plágio e, no mérito decidiram o concurso em favor da acusada. ${ }^{62}$

Considero, assim, que a hipótese em exame e a relatada por Jose Afonso da Silva, contém uma estreita afinidade que vale registrar. Por todo o exposto no presente entendo, também que, a exemplo do caso relatado, são infundadas as objeções formuladas com a finalidade de atribuir a prática de plágio a Carlos Alberto Dabus Maluf em sua tese "A inexistência na teoria das nulidades".

É o meu parecer.

São Paulo, 18 de junho de 2009.

62 Obra citada, p. 605 ainda. 